ENERGY DIVISION

\title{
THE POTENTIAL ECONOMIC IMPACT OF ELECTRICITY RESTRUCTURING IN THE STATE OF OKLAHOMA PHASE I REPORT
}

\author{
S. W. Hadley \\ C. R. Hudson \\ D. W. Jones
}

March 2001

Sponsored by

The Oklahoma Corporation Commission

P.O. Box 52000-2000

Oklahoma City, OK 73152-2000

OAK RIDGE NATIONAL LABORATORY

Oak Ridge, Tennessee 37831

managed by

UT-BATTELLE, LLC

for the

U.S. DEPARTMENT OF ENERGY

under contract No. DE-AC05-00OR22725 



\section{CONTENTS}

EXECUTIVE SUMMARY ....................................................................................................... V

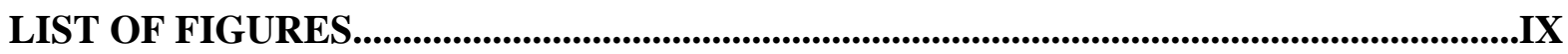

LIST OF TABLES.................................................................................................................................

ACRONYMS ................................................................................................................... XIII

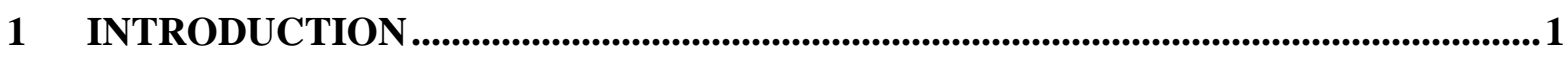

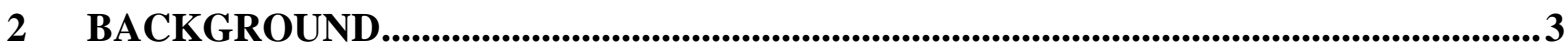

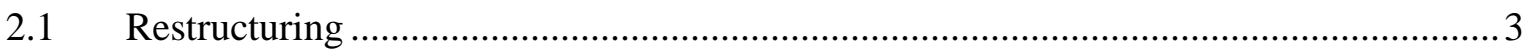

$2.2 \quad$ Electricity Pricing ...............................................................................................

3 OKLAHOMA MARKET DATA ...............................................................................................

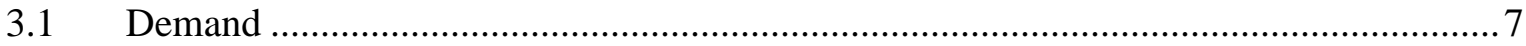

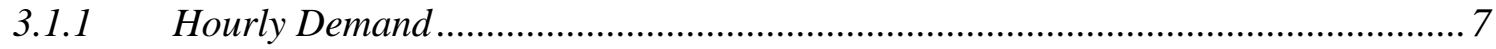

3.1.2 Convert to Load Duration Curve (LDC) for Two Seasons .................................... 8

3.1.3 Spread Total Demand Between Customer Classes …………….............................. 9

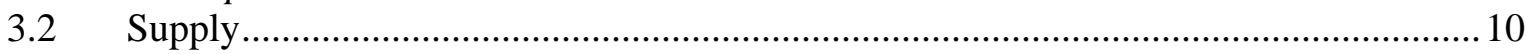

3.2.1 Inventory of Plants .................................................................................. 10

3.2.2 Financial Factors ................................................................................... 13

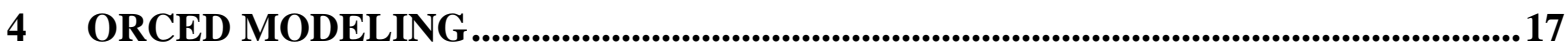

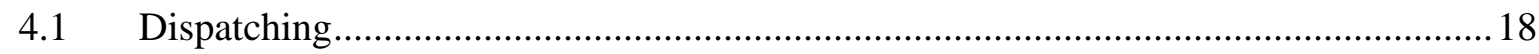

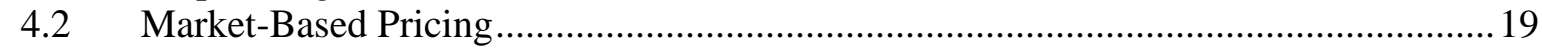

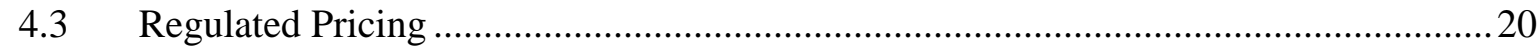

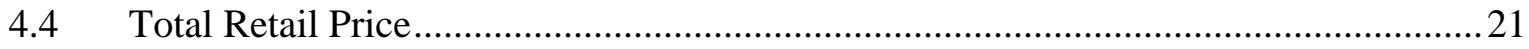

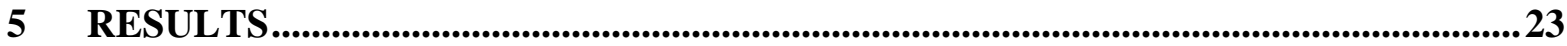

$5.1 \quad$ Regulated Versus Market Prices ………………………………………………...2

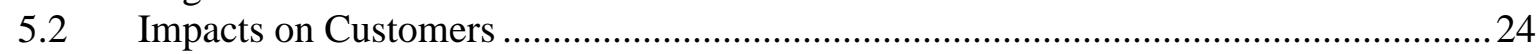

$5.3 \quad$ Financial Impacts on Production..............................................................................24

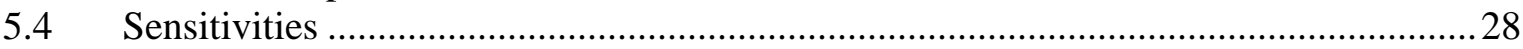

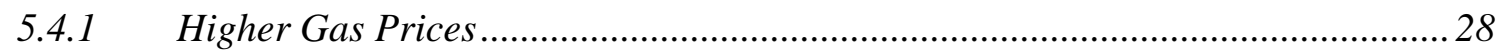

5.4.2 Higher Coal Plant Availability......................................................................... 31

6 CONCLUSIONS.....................................................................................................................35

7 REFERENCES ........................................................................................................................37 



\section{EXECUTIVE SUMMARY}

Because of the recent experiences of several states undergoing restructuring (e.g., higher prices, greater volatility, lower reliability), concerns have been raised in states currently considering restructuring as to whether their systems are equally vulnerable. Factors such as local generation costs, transmission constraints, market concentration, and market design can all play a role in the success or failure of the market. These factors along with the mix of generation capacity supplying the state will influence the relative prices paid by consumers.

The purpose of this project is to provide a model and process to evaluate the potential price and economic impacts of restructuring the Oklahoma electric industry. This Phase I report concentrates on providing an analysis of the Oklahoma system in the near-term, using only present generation resources and customer demands. In Phase II, a longer-term analysis will be conducted, incorporating the potential of new generation resources and customer responses.

Oak Ridge National Laboratory (ORNL) has developed the Oak Ridge Competitive Electricity Dispatch (ORCED) model to evaluate marginal-cost-based and regulated prices for the state. The model dispatches the state's power plants to meet the demands from all customers based on the marginal cost of production. Consequent market-clearing prices for each hour of the year are applied to customers' demands to determine the average prices paid. The revenues from the sales are paid to each plant for their generation, resulting in a net profit or loss depending on the plant's costs and prices when it operates.

Separately, the model calculates the total cost of generation, including fixed costs such as depreciation, interest and required return on equity. These costs are allocated among the customer classes to establish regulated prices for each class. These prices can be compared to the average market-based prices to see if prices increase or decrease with restructuring. An unchanging transmission and distribution (T\&D) component is added to both types of generation prices to determine the overall price of power to each customer class.

A base case was established for the state as a whole, using the set of plants and customer demands from 1999 based on data from various industry and government sources. Energy demands from the different customer classes were defined, including wholesale sales outside the state. Plant ownership by specific utilities, whether investor-owned, government, or cooperatives, was not used as a factor in the analysis, except in the generic cost of capital for the different types of utilities.

The results showed an average price increase of roughly one cent per kilowatt-hour under a restructured market (Figure S-1). This is because in a regulated market each plant will earn just enough to pay all costs and earn a reasonable return on equity. In a restructured market, where prices are based on marginal costs of the most expensive plant operating at any given time, some plants may earn little or nothing over the year while others earn more than the regulated rate of return. 
Figure S-1: 1999 retail prices and calculated market-based prices for each customer class. The T\&D component is constant in both scenarios.

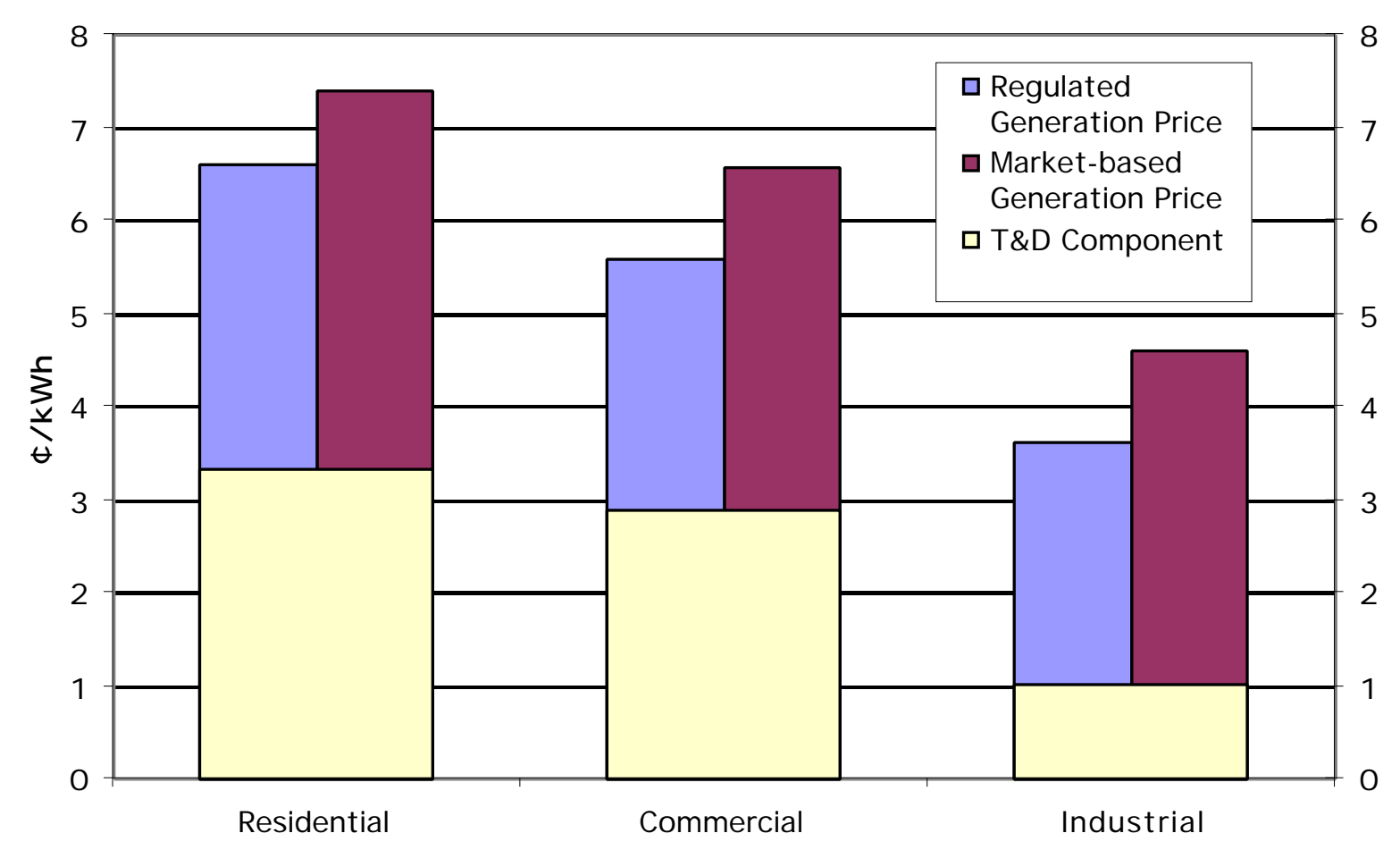

Two sensitivities were analyzed: one with higher gas prices, and one with higher coal plant availability (Figures S-2 and S-3). With average gas prices set closer to the average paid in 2000 (\$4.13/MBtu) rather than in 1999 (\$2.76/MBtu), market-based prices rose 25\% while regulated prices rose $9 \%$, after adding in a constant $T \& D$ rate to both. The net impact is that restructured prices were roughly two cents per kilowatt-hour higher than regulated prices. In the other sensitivity, increased availability of coal plants lowered the difference between market-based and regulated prices, although prices remained higher when market-based. Furthermore, this also caused gas-fired plants to run less often such that more of them became unprofitable (Figure S4). If prices were raised to restore their profitability to the amount in the base case, the result was higher prices to consumers.

Overall, Oklahoma is a low-cost power state. However, this statement masks the fact that it is a mixture of low-cost coal-fired plants and mid-cost gas-fired plants. In a regulated market with prices based on average costs, the costs of all production are combined to provide relatively low costs to customers. However, in a restructured market the market-clearing price will largely be defined by the price of the highest marginal cost plant operating at any one time. In Oklahoma, this will be gas-fired capacity most of the time. Consequently, prices will rise so these plants will recover their marginal costs. The low-cost coal plants will receive these higher prices as well, resulting in higher earnings than under regulated rates (Figure S-4). 
Figure S-2: Regulated and market-based customer prices from the base case and sensitivity with high gas prices.

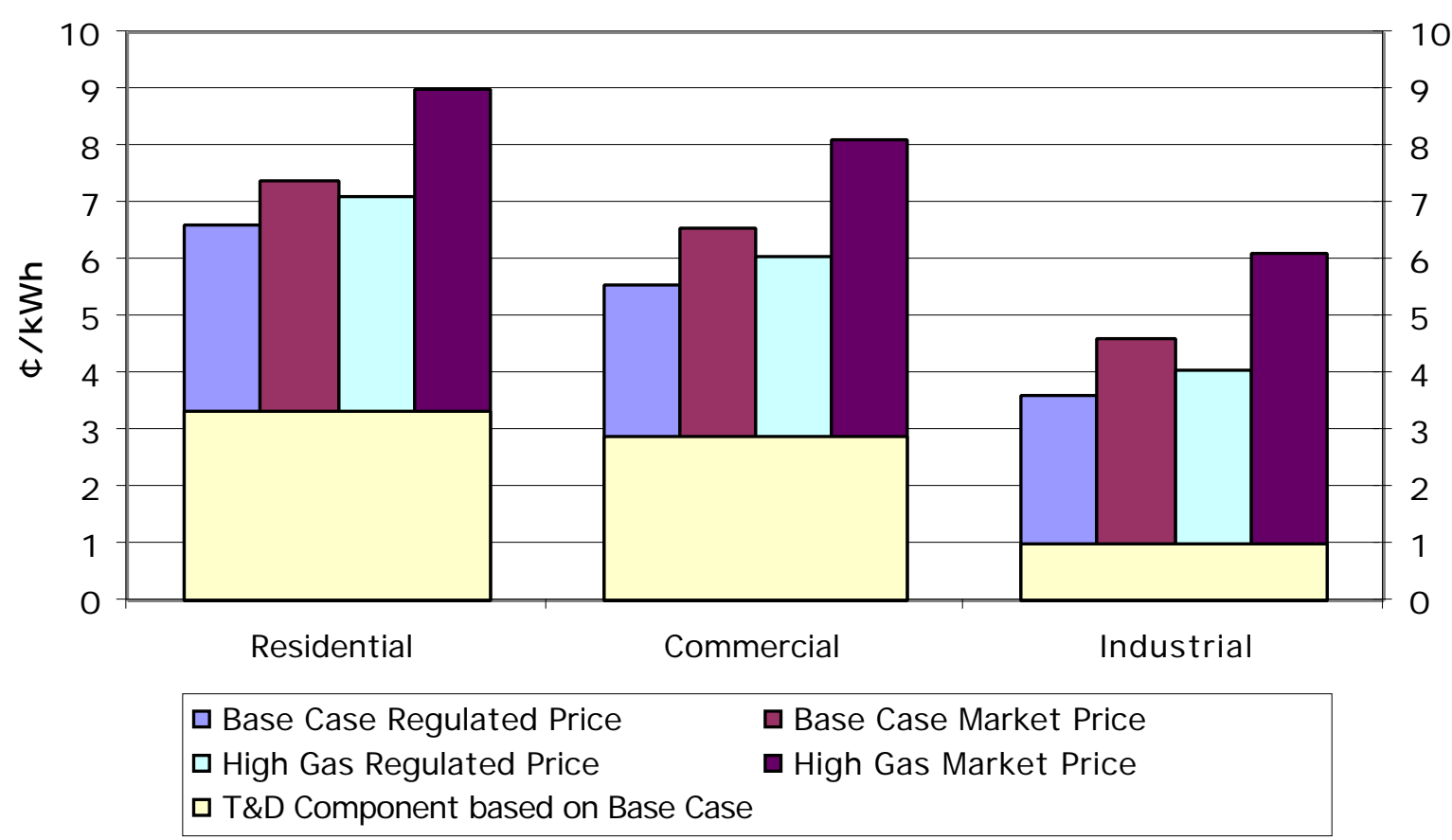

Figure S-3: Customer prices from the base case and sensitivity with higher coal plant availability before adjustment for profitability equalization.

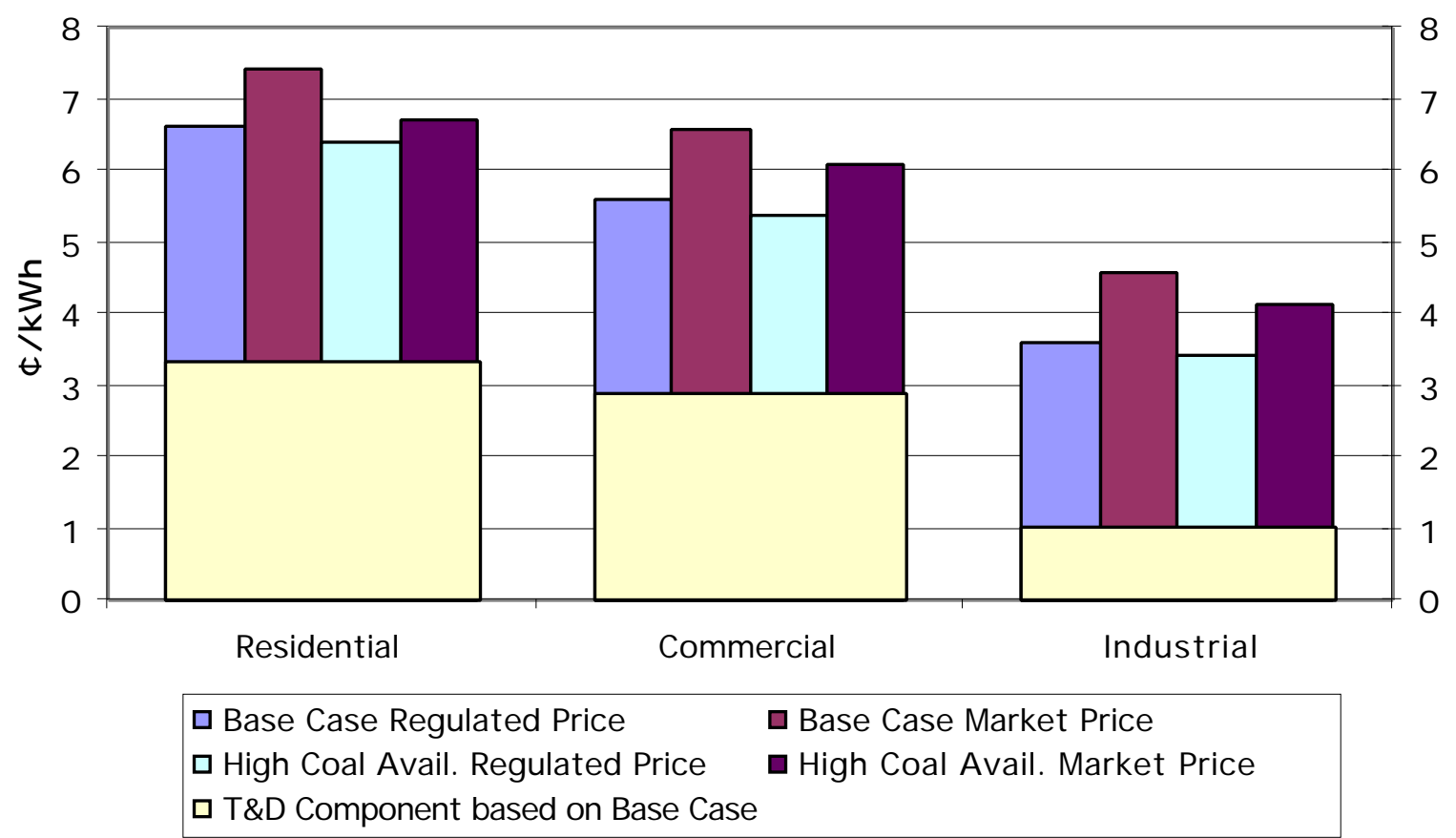


Figure S-4: Net income for major plant types with market-based and regulated prices, including sensitivities of higher natural gas prices and higher coal plant availability

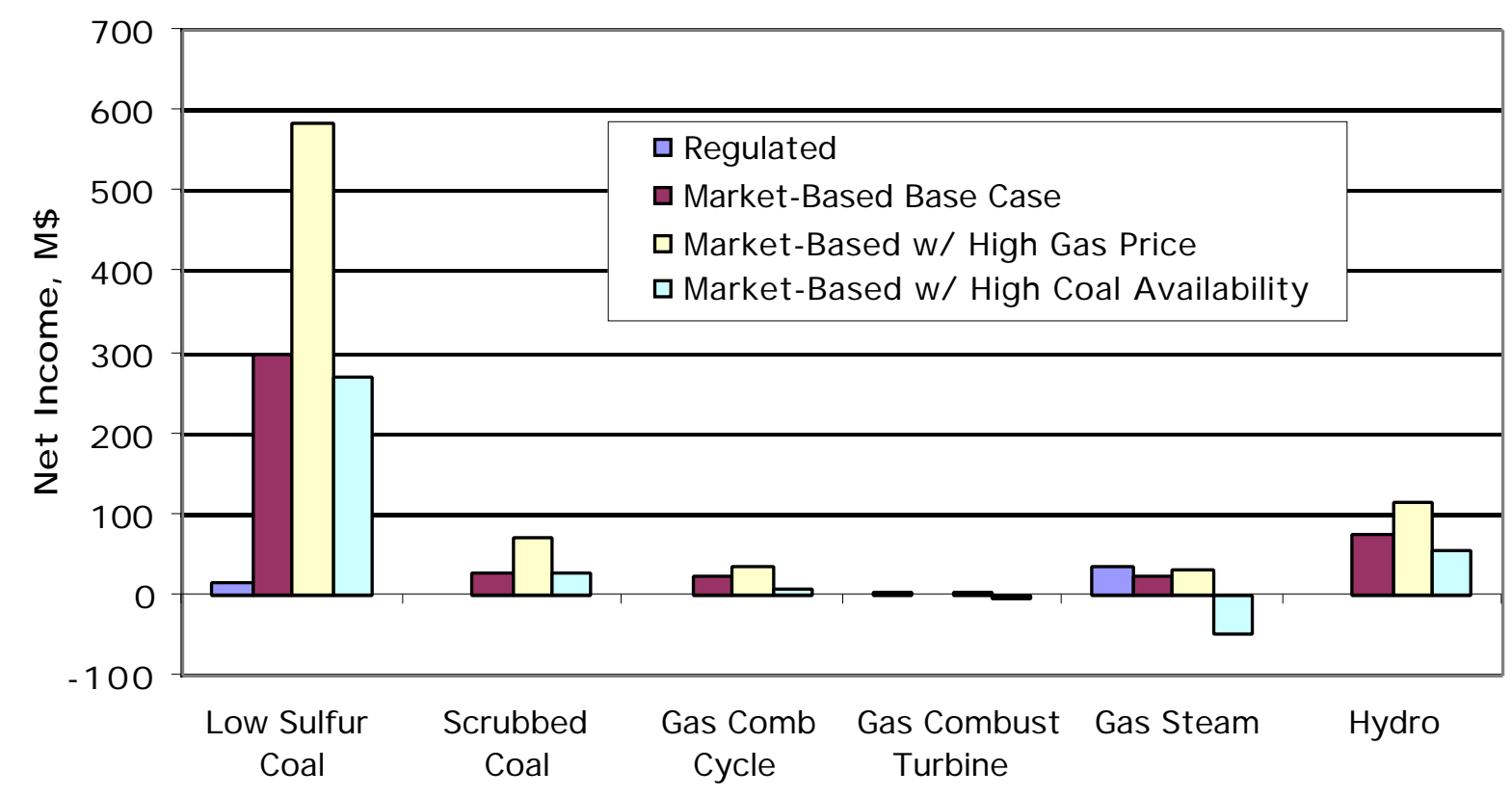

In some states that have restructured, the utilities have been faced with "stranded costs", costs that were approved to be recovered in a regulated market but are not recoverable in a restructured market. Oklahoma is faced with the opposite situation; the combined net income of all plants will be higher in a restructured market. Some plants' net income will be much higher while others may face profitability problems. This may lead to even higher prices. State decision-makers should consider this issue when designing any transition to a restructured electric generation market. 


\section{LIST OF FIGURES}

Figure S-1: 1999 retail prices and calculated market-based prices for each customer class..........iv

Figure S-2: Regulated and market-based customer prices from the base case and sensitivity with high gas prices

Figure S-3: Customer prices from the base case and sensitivity with higher coal plant availability before adjustment for profitability equalization.....

Figure S-4: Net income for major plant types with market-based and regulated prices, including sensitivities of higher natural gas prices and higher coal plant availability .........................vi

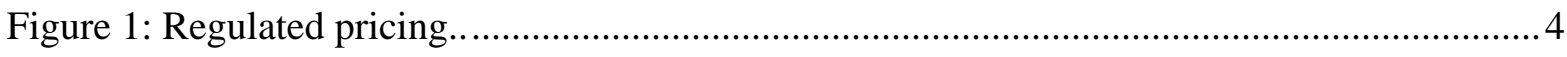

Figure 2: Industry supply under deregulated prices ............................................................. 5

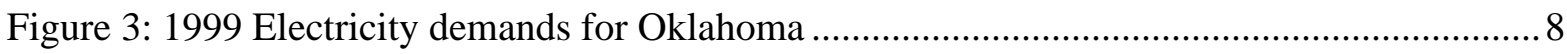

Figure 4: Calculated peak and off-peak LDC's closely match the actual curves. ........................ 9

Figure 5: Customer class peak and off-peak LDC's ........................................................... 10

Figure 6: Variable costs and capacities for 97 non-hydro consolidated plants in Oklahoma ....... 12

Figure 7: Supply curve for Oklahoma power plants .............................................................. 13

Figure 8: Peak dispatch of plants to meet demand from ORCED........................................... 18

Figure 9: Off-peak dispatch of plants to meet demand from ORCED ...................................... 18

Figure 10: Market prices based on variable costs of last plant dispatched ................................ 19

Figure 11: 1999 retail prices and calculated market-based prices for each customer class..........24

Figure 12: Net income for different plant types under market-based and regulated prices ..........26

Figure 13: Net income per kWh for plant types under market-based and regulated pricing ........27

Figure 14: Regulated and market-based customer prices from the base case and with high gas prices .

Figure 15: Net income for plant types with market-based and regulated prices, including market

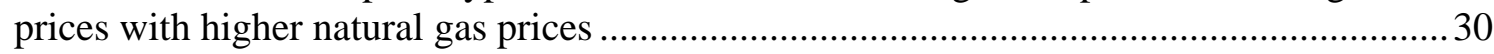

Figure 16: Net income for plant types in cents/kWh for base case and high gas price sensitivity case

Figure 17: Customer prices from the base case and with higher coal plant availabilities ............32

Figure 18: Net income for plant types under sensitivities with higher coal availability.............. 33 



\section{LIST OF TABLES}

Table 1: Oklahoma minimum and maximum electricity demands, MW and GWh....................7

Table 2: Retail demands converted to busbar loads and peak demands. ................................. 10

Table 3: Planned and forced outage rate calculation for coal plants based on average capacity

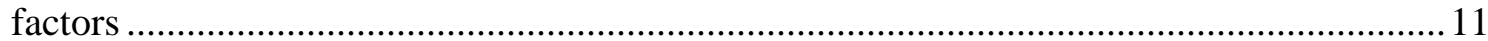

Table 4: Financial parameters for IOUs, municipal utilities, and rural coops in ORCED........... 13

Table 5: Example Balance Sheet for 122 MW gas-fired steam plant refurbished in 1990, M\$ ... 14

Table 6: Example Income Statement for $122 \mathrm{MW}$ gas-fired steam plant, M\$ .......................... 15

Table 7: Total Revenue Requirements under regulated pricing .............................................20

Table 8: Regulated demand charge calculation...................................................................... 21

Table 9: Regulated energy charge calculation ............................................................... 21

Table 10: Average regulated and market prices, $\phi / \mathrm{kWh}$....................................................... 23

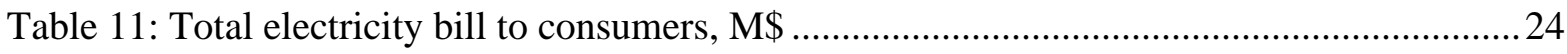

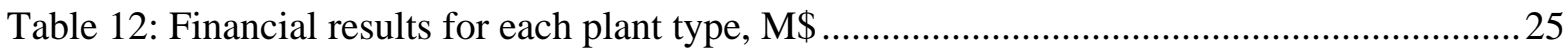

Table 13: Market finances for plant types in cents/kWh...................................................26

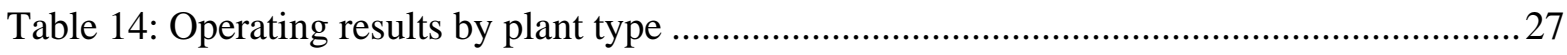

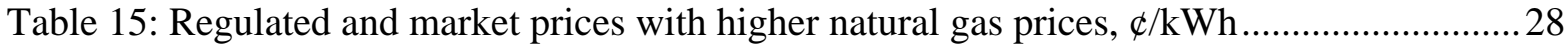

Table 16: Percentage price increases of high gas price case over base case ...............................28

Table 17: Power plant financial results with high gas prices, $\mathrm{M} \$$............................................29

Table 18: Market finances for plant types in cents/kWh for high gas price sensitivity ...............30

Table 19: Increase in market-based prices compared to regulated prices with added availability

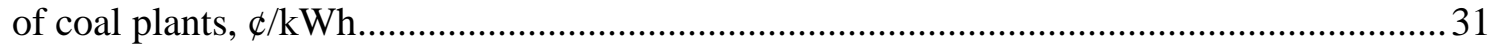

Table 20: Financial results for each plant type with higher coal plant availability, $\mathrm{M} \$$...............33 



\section{ACRONYMS}

$\begin{array}{ll}\text { EIA } & \text { Energy Information Administration } \\ \text { EPACT } & \text { Energy Policy Act of } 1992 \\ \text { FERC } & \text { Federal Energy Regulatory Commission } \\ \text { IOU } & \text { Investor-Owned Utility } \\ \text { LDC } & \text { Load Duration Curve } \\ \text { NEMS } & \text { National Energy Modeling System } \\ \text { NERC } & \text { North American Electric Reliability Council } \\ \text { O\&M } & \text { Operations and Maintenance } \\ \text { OCC } & \text { Oklahoma Corporation Commission } \\ \text { ORCED } & \text { Oak Ridge Competitive Electricity Dispatch model } \\ \text { ORFIN } & \text { Oak Ridge Financial model } \\ \text { ORNL } & \text { Oak Ridge National Laboratory } \\ \text { RDI } & \text { Resource Data International } \\ \text { SB } & \text { Senate Bill } \\ \text { T\&D } & \text { Transmission and Distribution }\end{array}$




\section{Introduction}

In April 1997, the Oklahoma legislature passed a bill to restructure the state's electric industry, requiring that the generation sector be deregulated and allowing retail competition by July 2002. Details of the market structure were to be established later. Senate Bill \#220, introduced in the 2000 legislature, provided additional details on this market, but the bill did not pass. Subsequent discussions have identified the need for an objective analysis of the impact of restructuring on electricity prices and the state's economy, especially considering the experiences of other states following restructuring of their electric systems.

Because of the recent experiences of other states undergoing restructuring (e.g., higher prices, greater volatility, lower reliability), concerns have been raised in states currently considering restructuring as to whether their systems are equally vulnerable. Factors such as local generation costs, transmission constraints, market concentration, and market design can all play a role in the success or failure of the market. Energy and ancillary services markets both play a role in having a well-functioning system. Customer responsiveness to market signals can enhance the flexibility of the market.

The purpose of this project is to provide a model and process to evaluate the potential price and economic impacts of restructuring the Oklahoma electric industry. The goal is to provide sufficient objective analysis to the Oklahoma legislature that they may make a more informed decision on the timing and details of any future restructuring. It will also serve to inform other stakeholders on the economic issues surrounding restructuring. The project is being conducted in two phases. The current report addressing Phase I concentrates on providing an analysis of the Oklahoma system in the near-term, using only present generation and transmission resources. In Phase II, a longer-term analysis will be conducted, incorporating the potential of new generation resources. Also, constraints and possible transmission and generation upgrades to the system will be studied, both institutional and physical. The market structure and rules under the various scenarios will be compared to each other, as well as to examples in other states that have undergone restructuring. As time and funding permits, multiple scenarios will be developed, adding various characteristics of a restructured market.

During the initial phase of the analysis, Oak Ridge National Laboratory (ORNL) developed a benchmark or base case based on the existing set of plants, customer demands, and regulated power prices. Generation and electric market data were gathered from the Department of Energy's Energy Information Administration (EIA), Resource Data International (RDI), the North American Electric Reliability Council (NERC), and the Oklahoma Corporation Commission (OCC). An ORNL-specialized model, the Oak Ridge Competitive Electricity Dispatch (ORCED) model, was used to evaluate the marginal-cost-based prices for the state. This analysis concentrated on the price impacts of changing from a regulated to a deregulated market design. An evaluation of the consequences of electricity price changes on the Oklahoma economy will be conducted in the second phase of this effort. This involves a broader look at the electric sector's influence on the overall economy, and societal response to changes in the market. 



\section{Background}

\subsection{Restructuring}

Changing electric power generation in the United States from a regulated industry to a partially deregulated industry is under consideration in many quarters. The long-standing vertically-integrated structure of the industry, where investor-owned utilities (IOUs) owned most of the generation capacity, transmission, and distribution facilities, was based in part on the economic theory that electric power production and delivery were natural monopolies, and that large centralized power plants were the most efficient and inexpensive means for producing electric power and delivering it to customers. Large power generating plants, integrated with transmission and distribution systems, achieved economies of scale and lower operating costs than relatively smaller plants could realize. Because of the monopoly structure, Federal and State government regulations were developed to control operating procedures, prices, and entry to the industry in order to protect consumers from potential monopolistic abuses.

Several factors have led to consideration of a more competitive marketplace for generation. First, technological advances have altered the economics of power production. For example, new gas-fired combined cycle power plants are more efficient and competitive with older power plants. Also, technological advances in electricity transmission equipment have made possible the economic transmission of power over long distances so that customers can now be more selective in choosing an electricity supplier. Second, between 1975 and 1985, residential electricity prices and industrial electricity prices rose 13 percent and 28 percent in real terms, respectively. These rate increases, caused primarily by increases in utility construction and fuel costs, caused government officials and others to call into question the existing regulatory environment. Third, the effects of the Public Utilities Regulatory Policies Act of 1978, which encouraged the development of non-utility power producers that used renewable energy to generate power, seemed to demonstrate that traditional vertically integrated electric utilities were not the only source of reliable power.

Competition in wholesale power sales received a boost from the Energy Policy Act of 1992 (EPACT), which expanded the Federal Energy Regulatory Commission's (FERC's) authority to order vertically integrated IOUs to allow non-utility power producers access to the transmission grid to sell power in an open market. Subsequent FERC Orders (e.g., Orders 888, 889, and 2000) have provided a structure for increased competition in wholesale electricity markets. In addition to wholesale competition, retail competition has started in many States. As of July 1, 2000, 24 States and the District of Columbia had passed laws or regulatory orders to implement retail competition.

In Oklahoma, bills requiring the establishment of retail competition were passed by the legislature in 1997 and 1998 (SB 500 and SB 888). Last year, a bill (SB 220) containing details of how to implement retail competition in the state's electric power industry, set to begin July 1, 2002, was defeated in the House. Reconsideration of legislation containing implementation guidelines may take place in the 2001 legislative session. 


\subsection{Electricity Pricing}

For the purposes of ORNL's electricity-price simulations, the principal difference between regulation and non-regulation is in calculating the components of prices. One of the goals of regulated prices is to insure that producers receive revenues that cover their fixed and variable costs, including an allowance for a "reasonable rate of return" on their capital investments. Another goal is to protect consumers from the potentials of predatory pricing by suppliers with local monopoly power. This leads to prices based on the total revenue requirements of the system allocated to customers based on their energy use. Unregulated, market-clearing prices are based on the highest bid price of all the plants operating at any given time. Bid prices are typically based on the marginal cost of production of this last plant, so do not necessarily cover the fixed costs of the other operating plants, or may be in excess of the amount needed for cost recovery.

An important technical condition entering into the supply side of the electricity market, whether regulated or not, is that the marginal cost of meeting demand at peak times is higher (sometimes much higher) than the cost of supplying lower demands of electricity-off-peak loads. Regulated pricing typically protects consumers from the full cost of peak loads by selecting electricity rates (prices) that are slightly higher than full-cost-recovery during most periods but that may be considerably lower than costs at peaks, particularly at very high annual peaks. Over the year, the periods during which generators' costs exceed what they can charge at regulated prices are expected to be compensated with the modest excess over full cost-recovery they charge for the other times. Figure 1 demonstrates this averaging-out for a single supplier.

Figure 1: Regulated pricing. More hours of non-peak demand make triangle A (with regulated price higher than cost) larger relative to triangle $\mathrm{B}$ (with regulated price less than cost).

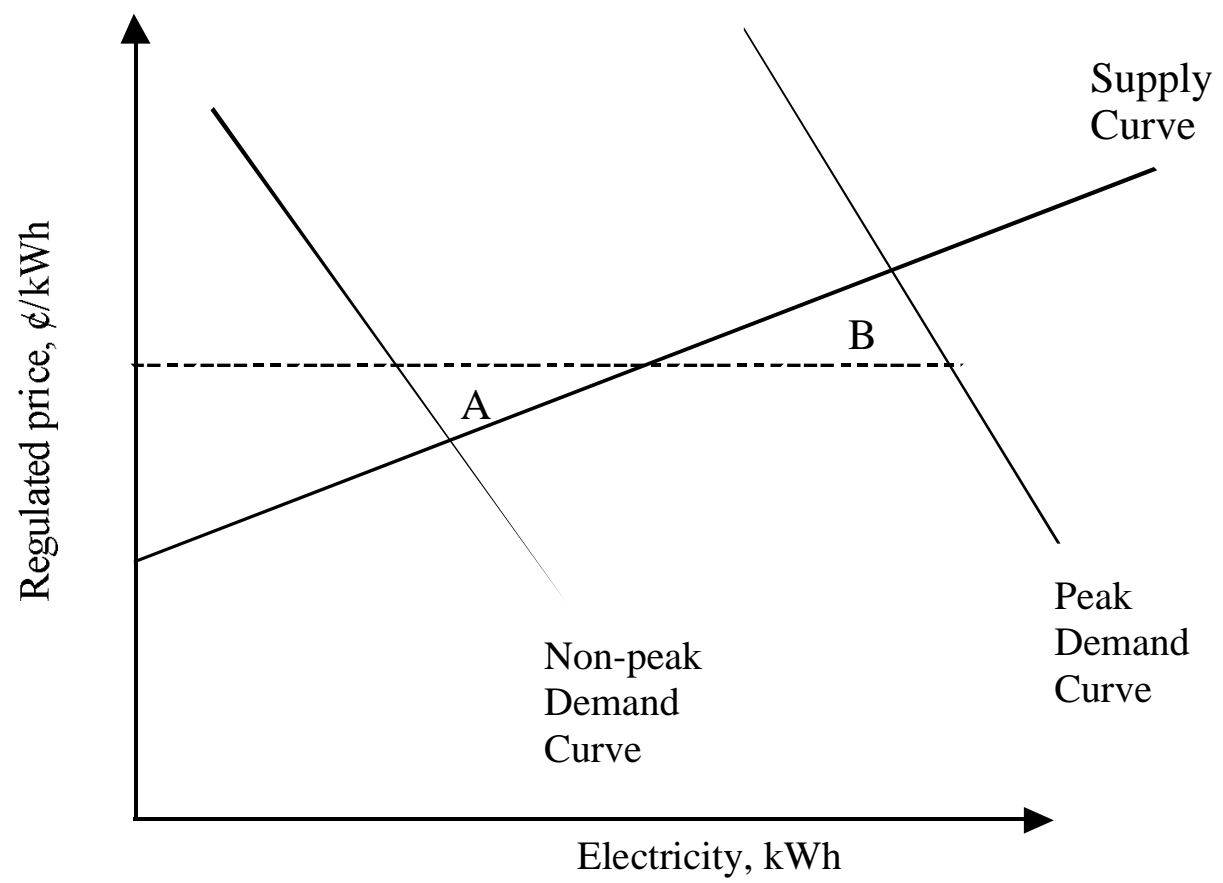

Oklahoma Restructuring Impact 
Deregulation changes this structure of charges. Instead of intentionally smoothing out the price that consumers face, a deregulated electricity market lets the price of electricity be determined by the direct, and time-varying, interaction of demand (load) and supply (generation), and the marginal cost involved with meeting demand increase. Figure 2 shows the market determination of the electricity price over one such period of the year, but for the entire regional electricity market rather than for a single generator. The cost of supplying the last units of electricity demanded determines the single, market price of electricity at that point in time. The demand curve will move left and right throughout the year as customers' needs increase or decrease.

Figure 2: Industry supply under deregulated prices. Area labeled Supplier Surplus represents earnings over and above the marginal costs earned by lower-cost generators when a single price, $\mathrm{P}^{*}$, is determined by the marginal cost of the generator who supplies the last units of electricity demanded.

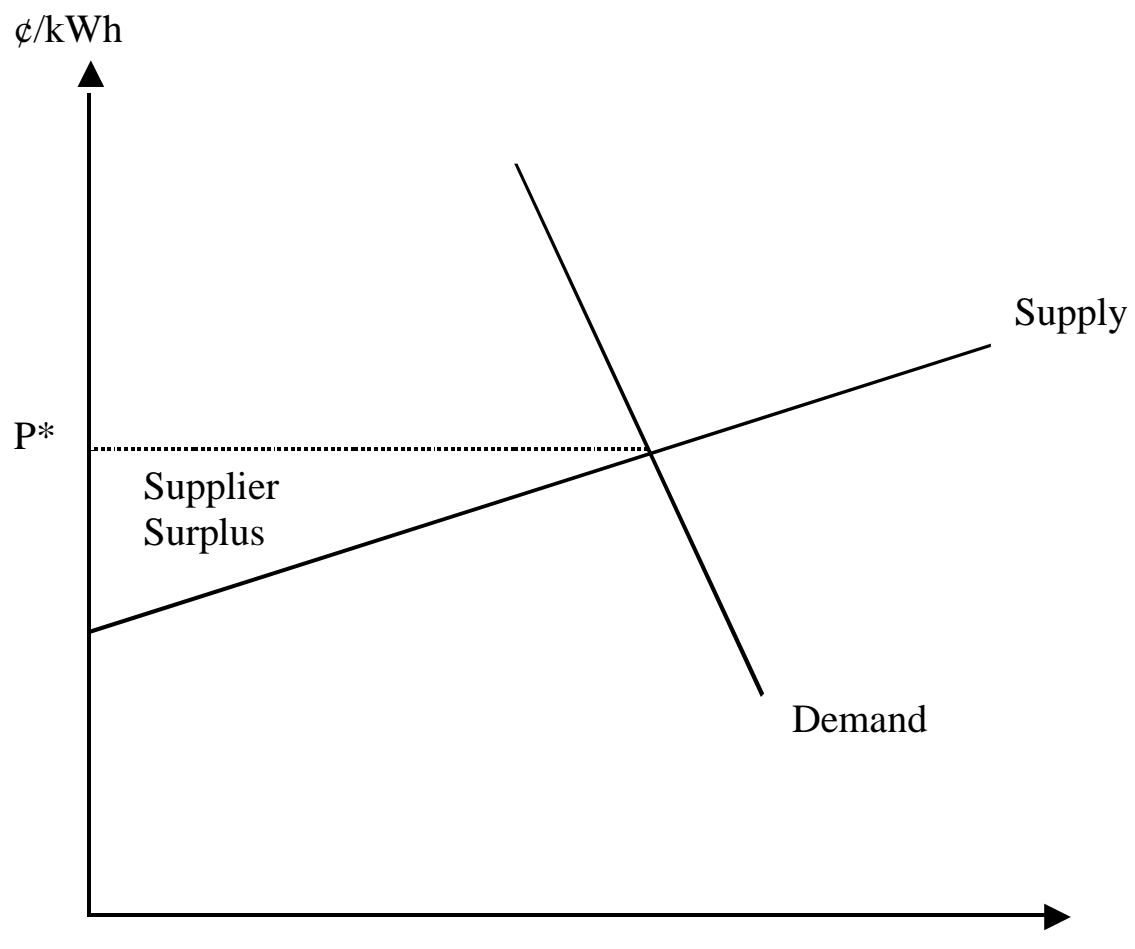

Electricity

An important difference between the regulated and deregulated electricity market is that regulated prices are set according to the full costs of the sum of the individual generators. The consequences of this feature of regulation can best be seen by comparing the deregulated situation. With deregulation, the market sets "the" price for all generators, more efficient ones and less efficient ones alike. With a single price determined by the intersection of demand and supply, as in Figure 2, more efficient generators receive a price potentially well above their generation costs, which can give some generators quite high rates of return and others much lower ones. 
The ORCED model simulates the OCC-regulated, full-cost-based price from the ratio of total revenue requirements to total sales, allocated between customer classes. The revenue requirements include variable and start-up costs, net power-purchase costs, fixed operations and maintenance (O\&M) costs, and capital costs over the entire year. Capital costs include depreciation, interest, taxes, and a reasonable rate of return. To simulate deregulated prices, load from the entire state is confronted with a state-wide supply curve, and a single, separate marketclearing price is calculated for each hour of the year.

The increase in the deregulated prices over their regulated counterparts reflects the ability of generators to charge full marginal cost. The marginal cost of the supplier who brings in the last units of supply essentially determines the price for the entire electricity market. Furthermore, if generators are able to charge above full marginal cost, through whatever means, then prices to customers will reflect this above-marginal cost. 


\section{Oklahoma Market Data}

In order to model the Oklahoma electricity market, we collected data from a number of sources. Utilities must submit a large amount of financial and operations information to the FERC and the EIA. RDI collects this publicly available information, categorizes it, performs some quality checks on it, and distributes it in a convenient computer program called Powerdat (RDI 2001). Much of the data for the year 2000 is not available yet, so 1999 was picked as the base year. In addition, the state's utilities responded to requests from the OCC for certain sets of information, notably customer load factors, peak demands, and available capacity. These data were used as a supplement to the electronic data from EIA and RDI.

\subsection{Demand}

Demand is based on reports from power control centers specifying their load for each hour. Data from RDI are for 23 utilities in the Southwest Power Pool. Five of these have significant sales inside of Oklahoma (Table 1). Separately, several of these utilities provided information on their peak power levels. The Public Service Oklahoma and Central and Southwest Power data are combined in the raw data, based on their combined planning area. PSO separately provided information through the OCC on their peak demand, so the hourly data of the two combined were prorated $41 \%$ to approximate the PSO portion. Similarly, Oklahoma Gas \& Electric and Western Farmers Electric Coop provided their own information on peak demands, so their hourly demands were prorated so that the peak levels from the RDI data matched their information.

Table 1: Oklahoma minimum and maximum electricity demands, MW and GWh

\begin{tabular}{|c|c|c|c|}
\hline Name & Minimum & Maximum & Total Energy \\
\hline Public Service Oklahoma & 1,226 & 3,794 & 17,260 \\
\hline Grand River Dam Authority & 370 & 1,274 & 5,452 \\
\hline Oklahoma Gas \& Electric Co. & 1,806 & 5,563 & 25,358 \\
\hline Oklahoma Municipal Power Authority & 115 & 605 & 2,134 \\
\hline Western Farmers Electric Coop & 351 & 1,128 & 5,317 \\
\hline Total & 3,868 & 12,364 & 55,521 \\
\hline
\end{tabular}

\subsubsection{Hourly Demand}

The 8760 hourly loads from each of the utilities were combined to create hourly demands for the state (Figure 3). As can be seen, the peak demands are much higher in the summertime than the rest of the year. For modeling within ORCED, the year must be split between a peak and offpeak season. Rather than use June through August, the peak season was extended to September 16 , to capture the peak levels in early September. Consequently the peak equals $30 \%$ of the year. 
Figure 3: 1999 Electricity demands for Oklahoma

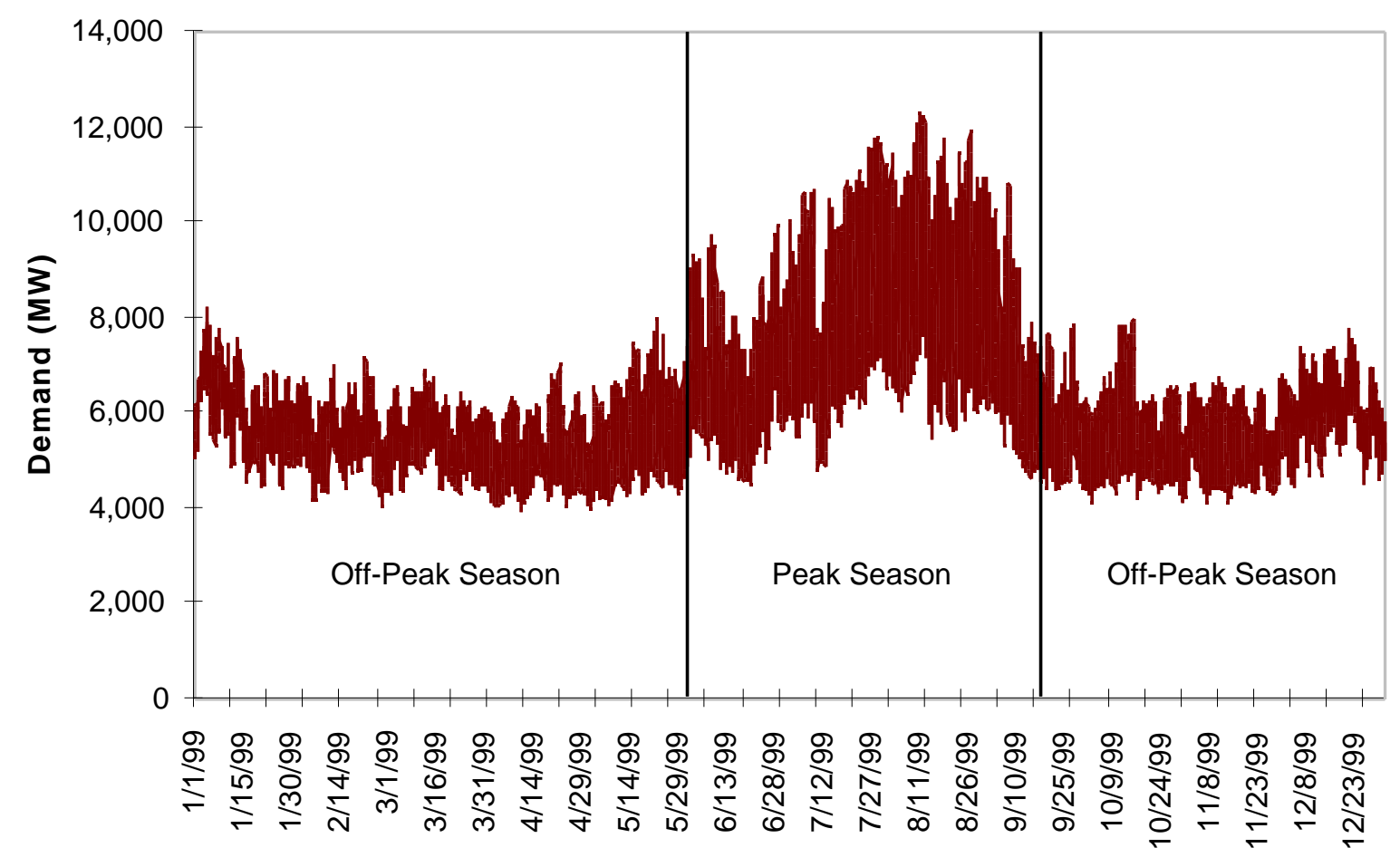

\subsubsection{Convert to Load Duration Curve (LDC) for Two Seasons}

The two seasons are treated slightly differently within ORCED. In the peak season no outages are planned, and the only outages that happen are random forced outages. In the off-peak season, power plant capacities are derated to represent the portion of time they have planned outages, in addition to having forced outages.

The power loads from all of the hours of each season were stacked in increasing order to create the LDC for each season (Figure 4). The curves show the percentage of time that demand was at least a given power level. For example, during the peak season, demand was $5000 \mathrm{MW}$ or greater $100 \%$ of the time. For $50 \%$ of the season, demand was $7500 \mathrm{MW}$ or greater, and for $10 \%$ of the season, demand was $11,000 \mathrm{MW}$ or greater. The off-peak season has a lower, flatter curve than the peak season because of the lack of air-conditioning loads that so drive the peak during the summer months. Combined, the two curves create the annual LDC. 
Figure 4: Calculated peak and off-peak LDC's closely match the actual curves.

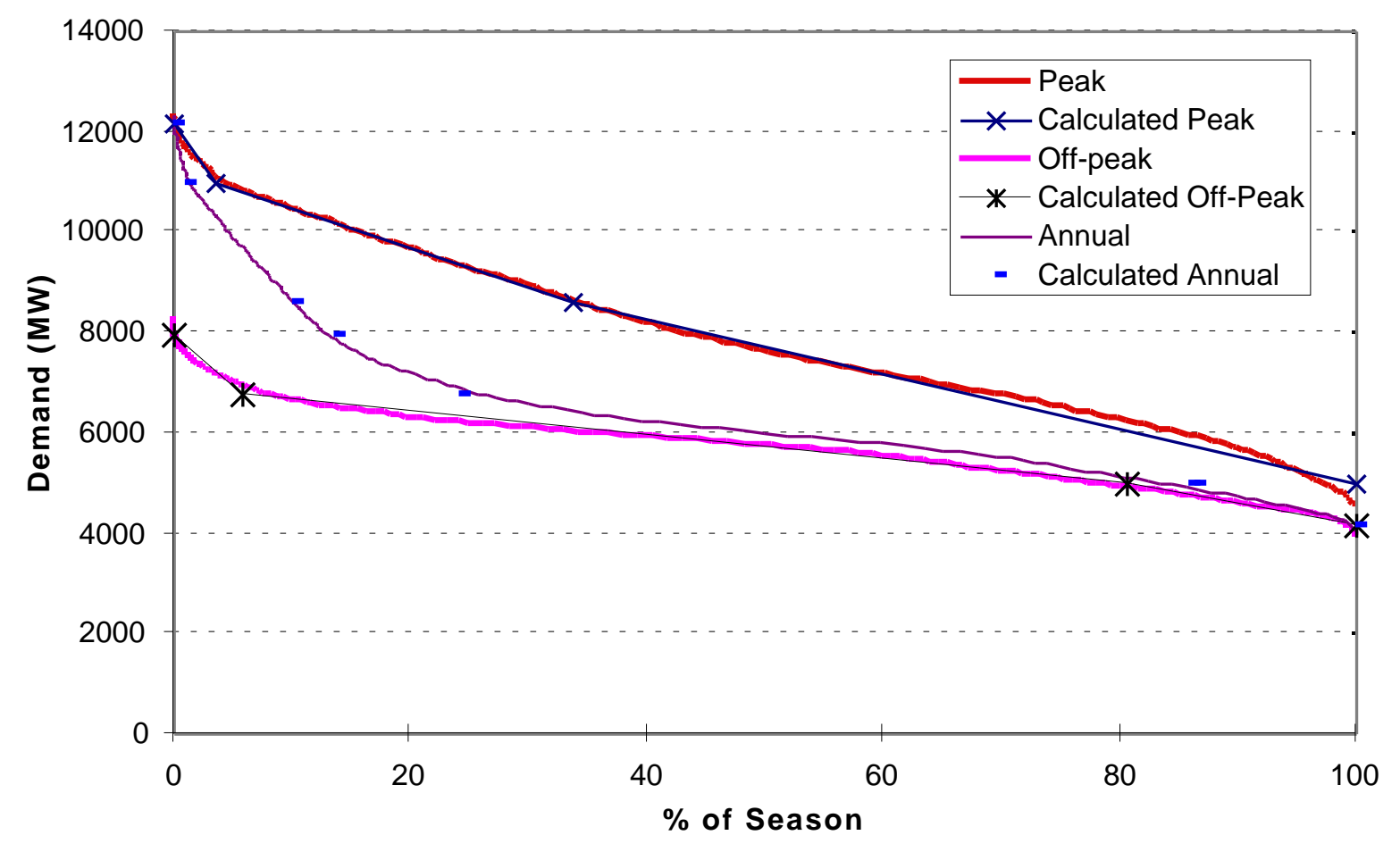

In order to use the data in the ORCED model a four-segment curve is fitted to each demand curve. These are shown in the figure above and labeled as the calculated curves.

\subsubsection{Spread Total Demand Between Customer Classes}

So far, demand has been determined by the system hourly demands as reported by the different utilities. Separately, annual retail sales for each customer class are also available (RDI 2001). To determine the load shape of each class, it is necessary to match their demands so that they sum to the system demand. Power losses and load factors for each customer class that are reasonable approximations of the actual values must be used to convert retail sales into busbar loads throughout the year. Beyond retail sales, there are wholesale sales from the Oklahoma power plants to other states. Based on historical information from EIA, this amounts to approximately $11 \%$ of retail sales. Other sales not included in the residential, commercial, or industrial sectors (such as public lighting) are included in the Other category.

Peak and off-peak load duration curves for each class were fitted so that their sum matched the total system load (Figure 5). These give sales and load factors for each customer type as shown in Table 2. 
Figure 5: Customer class peak and off-peak LDC's

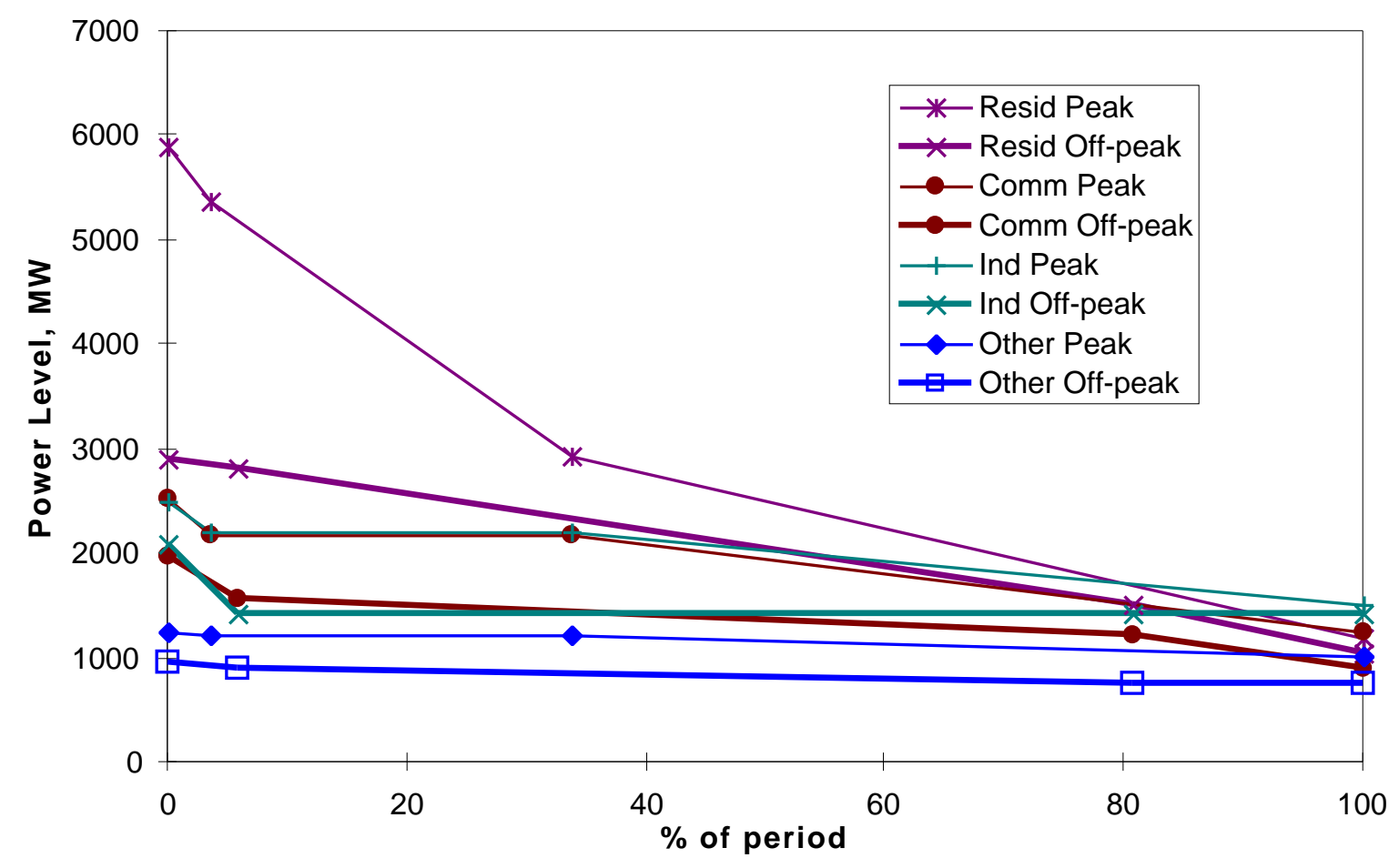

Table 2: Retail demands converted to busbar loads and peak demands.

\begin{tabular}{l|ccccc} 
Customer Class & Retail GWh & Losses & Busbar GWh & Peak MW & Load Factor \\
\hline Residential & 18,301 & $8 \%$ & 19,893 & 5,882 & $39 \%$ \\
Commercial & 12,398 & $6 \%$ & 13,190 & 2,525 & $60 \%$ \\
Industrial & 13,271 & $5 \%$ & 13,970 & 2,489 & $64 \%$ \\
Other & 7,603 & $6 \%$ & 8,088 & 1,237 & $75 \%$ \\
Total Demand & 51,573 & & 55,140 & 12,134 & $52 \%$
\end{tabular}

\subsection{Supply}

Markets involve both supply and demand. In ORCED, supply for a region is defined by up to 200 individual plants, each with its own operation and financial parameters.

\subsubsection{Inventory of Plants}

The power plants of Oklahoma were found using the Powerdat database from RDI (RDI 2001) plus the database that the EIA uses for their NEMS model (EIA 2000a). These list 177 power plant units within the state. Many power plants have multiple units, each with its own capacity, fuel cost, heat rate, age, and other factors. Many of the data required are available directly from the RDI database. However, for some data the database combines the values from multiple units into a single value. Some plants are not listed in the Powerdat database either, being too small or owned by an organization that does not have to report information to FERC. 
Fortunately, the EIA database is more comprehensive and includes these plants. It does not include fuel costs however, since the model for which the data are used (the NEMS model) calculates fuel costs internally. To find fuel costs, we used statewide averages of fuel costs for those plants, as determined by summing the monthly fuel costs reported by utilities to EIA (EIA 2000b).

Neither database contains forced outage and planned outage rates for the plants. The Generation Availability Data System from the North American Electric Reliability Council (NERC 1998) contains capacity-weighted statistics on availability and outages for each type of plant technology. This information can be used to determine the typical outage rates for each plant type. However, because the Oklahoma coal plants are a significant fraction (33\%) of capacity and are generally baseload plants, we calculated separate, plant-specific values for them. We assumed that their generation in the past three years was largely limited by forced and planned outages (as opposed to dispatch restrictions due to high cost.) We calculated the capacity factor for each coal plant for the peak (June-August) and off-peak seasons for 1997 through 1999 (Table 3).

Table 3: Planned and forced outage rate calculation for coal plants based on average capacity factors

\begin{tabular}{|c|c|c|c|c|c|c|}
\hline $\begin{array}{l}\text { Plant with } \\
\text { demonstrated } \\
\text { capacity }\end{array}$ & Year & $\begin{array}{c}\text { Peak Season } \\
\text { Capacity } \\
\text { Factor } \\
\end{array}$ & $\begin{array}{c}\text { Off-peak } \\
\text { Capacity } \\
\text { Factor } \\
\end{array}$ & $\begin{array}{l}\text { Annual } \\
\text { Capacity } \\
\text { Factor } \\
\end{array}$ & $\begin{array}{c}\text { Forced } \\
\text { Outage Rate }\end{array}$ & $\begin{array}{l}\text { Planned } \\
\text { Outage Rate }\end{array}$ \\
\hline Northeastern & 1997 & $95 \%$ & $88 \%$ & $90 \%$ & & \\
\hline \multirow[t]{3}{*}{$920 \mathrm{MW}$} & 1998 & $86 \%$ & $85 \%$ & $85 \%$ & & \\
\hline & 1999 & $86 \%$ & $68 \%$ & $72 \%$ & & \\
\hline & avg & $89 \%$ & $80 \%$ & $82 \%$ & $11 \%$ & $7 \%$ \\
\hline GRDA & 1997 & $77 \%$ & $67 \%$ & $69 \%$ & & \\
\hline \multirow[t]{3}{*}{$1010 \mathrm{MW}$} & 1998 & $82 \%$ & $63 \%$ & $68 \%$ & & \\
\hline & 1999 & $74 \%$ & $71 \%$ & $72 \%$ & & \\
\hline & avg & $78 \%$ & $67 \%$ & $70 \%$ & $22 \%$ & $8 \%$ \\
\hline Muskogee & 1997 & $81 \%$ & $75 \%$ & $76 \%$ & & \\
\hline \multirow[t]{3}{*}{1515 MW } & 1998 & $76 \%$ & $67 \%$ & $69 \%$ & & \\
\hline & 1999 & $69 \%$ & $65 \%$ & $66 \%$ & & \\
\hline & avg & $75 \%$ & $69 \%$ & $71 \%$ & $25 \%$ & $5 \%$ \\
\hline Sooner & 1997 & $93 \%$ & $77 \%$ & $81 \%$ & & \\
\hline \multirow[t]{3}{*}{1015 MW } & 1998 & $86 \%$ & $64 \%$ & $70 \%$ & & \\
\hline & 1999 & $85 \%$ & $72 \%$ & $75 \%$ & & \\
\hline & avg & $88 \%$ & $71 \%$ & $75 \%$ & $12 \%$ & $13 \%$ \\
\hline Hugo & 1997 & $42 \% *$ & $74 \%$ & $66 \%$ & & \\
\hline \multirow[t]{3}{*}{$408 \mathrm{MW}$} & 1998 & $88 \%$ & $75 \%$ & $78 \%$ & & \\
\hline & 1999 & $86 \%$ & $80 \%$ & $82 \%$ & & \\
\hline & avg & $87 \%$ & $78 \%$ & $80 \%$ & $13 \%$ & $7 \%$ \\
\hline
\end{tabular}


We assumed that the forced outage rates for these plants during the summer peak were equal to one minus the peak season capacity factor. The planned outage rates were the difference between the annual and peak season capacity factors. To check the impact of this assumption, we ran a sensitivity in which the coal plants were assigned the forced and planned outage rates that were calculated from the NERC availability data for coal technologies $(6.6 \%$ and $9.7 \%$ respectively.) The results are described in Section 5.4.2.

The 190 units in the state were consolidated into 99 plants for use within ORCED. Most units were kept as individual plants in the model, although hydro and pumped storage units were consolidated into two plants because of the way ORCED models these technologies. Also, the 36 municipal combustion turbines were consolidated down to 17 plants for simplicity. The capacities and operating costs for each of the plants can be seen in Figure 6. For example, Plants 1 through 10 are gas-fired steam plants with variable costs of around \$35/MWh. They range in capacity from 58 to $530 \mathrm{MW}$. Plants 11-20 are smaller, gas-fired combustion turbines, some relatively efficient and so with similar costs as the steam plants but some with much higher costs due to low efficiency. Coal plants, such as Plants 23-27, have much lower variable costs, around $\$ 10 / \mathrm{MWh}$. The hydroelectric and pumped storage plants are consolidated separately and not shown on the graph.

Figure 6: Variable costs and capacities for 97 non-hydro consolidated plants in Oklahoma

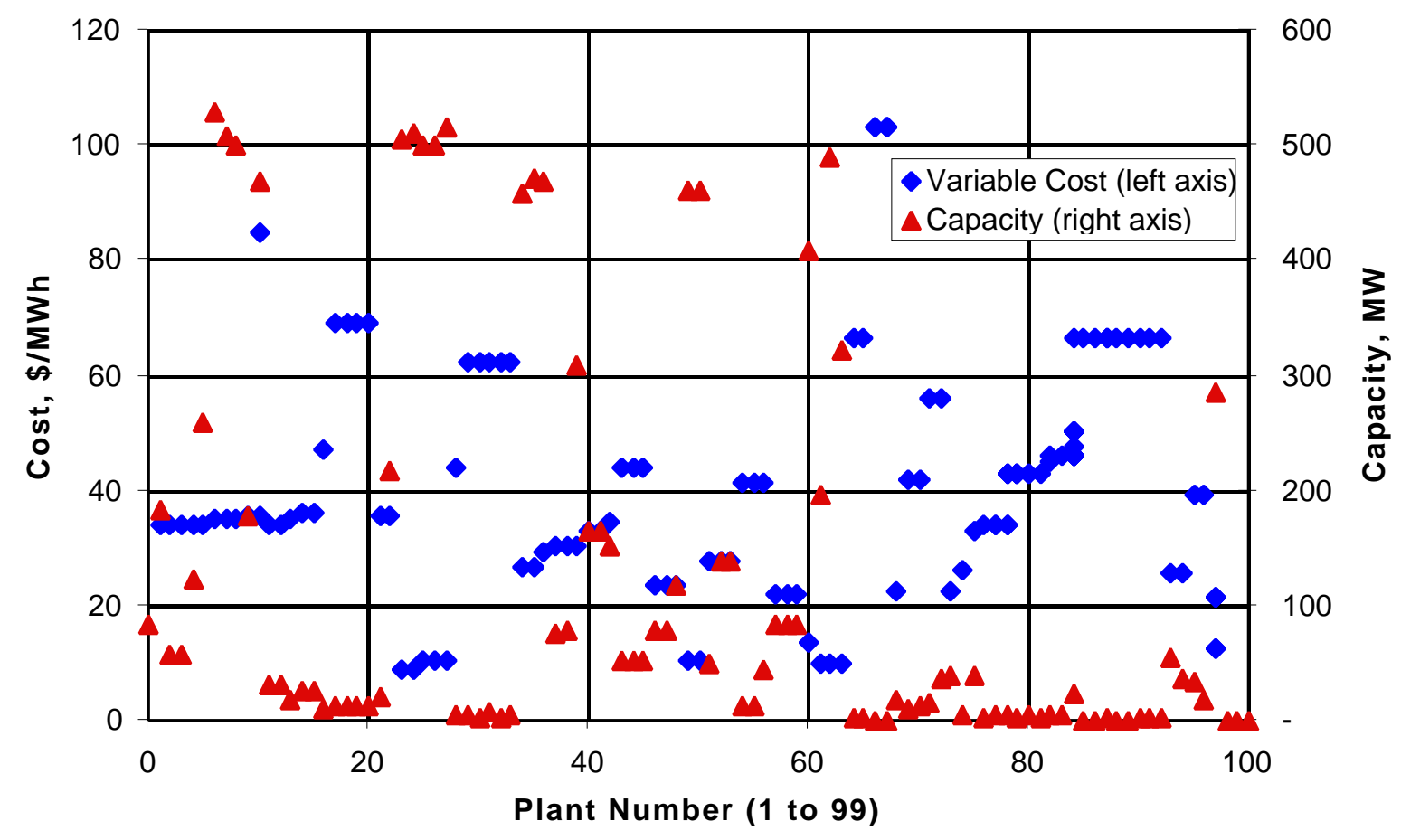

By arranging the plants in order of increasing cost, the supply curve (which is the basis for market prices) for power can be developed (Figure 7). The power supply at the left with a zero price comes either from must-run facilities (cogeneration that makes additional electricity as a 
by-product) or hydro facilities. In ORCED, these facilities do not bid into the market but rather accept whatever price is current.

\section{Figure 7: Supply curve for Oklahoma power plants}

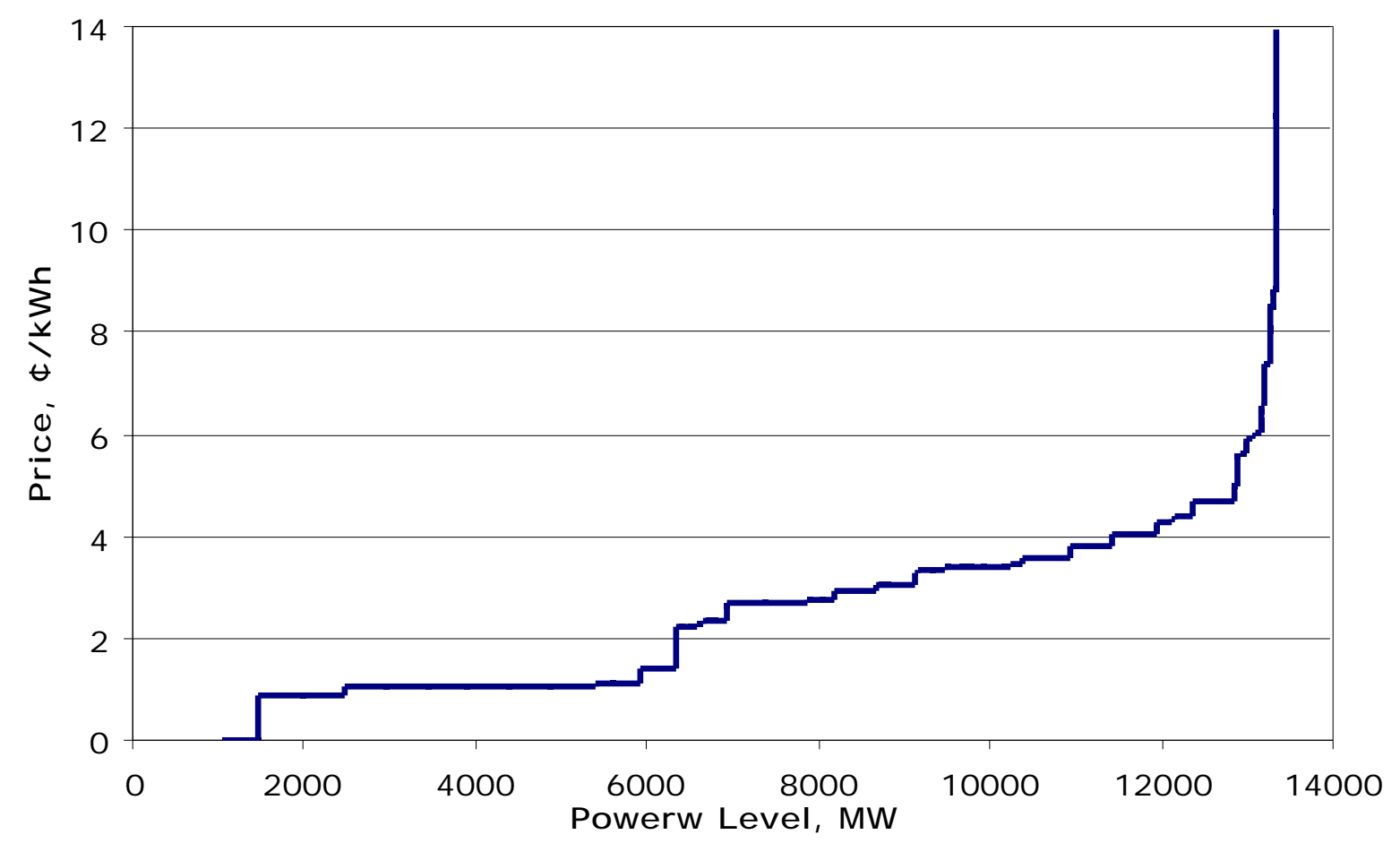

\subsubsection{Financial Factors}

Each plant's capital cost and age is carried over from the databases. Using financial parameters such as interest rate, tax rate, debt ratio, and required return on equity, the annual fixed capital costs can be calculated. Table 4 shows the financial parameters used for IOUs, municipal utilities and coops. Hydro plants are treated slightly differently in that they have a 50 year book life.

Table 4: Financial parameters for IOUs, municipal utilities, and rural coops in ORCED

\begin{tabular}{c|ccccccccc} 
Label & $\begin{array}{c}\text { Book Life } \\
\text { (Years) }\end{array}$ & $\begin{array}{c}\text { Tax Life } \\
\text { (Years) }\end{array}$ & $\begin{array}{c}\text { Income } \\
\text { Tax Rate }\end{array}$ & $\begin{array}{c}\text { Property Rax Rate } \\
\text { Debt } \% \text { of } \\
\text { total } \\
\text { Asset }\end{array}$ & $\begin{array}{c}\text { Debt } \\
\text { Interest } \\
\text { Rate }\end{array}$ & $\begin{array}{c}\text { Allowed } \\
\text { Equity } \\
\text { Return } \\
\text { Rate }\end{array}$ & $\begin{array}{c}\text { Capital } \\
\text { Expendit } \\
\text { ures } \\
\text { (\% Initial } \\
\text { Cost) }\end{array}$ & $\begin{array}{c}\text { Expendit } \\
\text { ures } \\
\text { Deprec. } \\
\text { Life }\end{array}$ \\
\hline $\begin{array}{c}\text { IOU } \\
\text { Muni and } \\
\text { Coop }\end{array}$ & 30 & 20 & $36 \%$ & $2 \%$ & $48 \%$ & $8.0 \%$ & $11.0 \%$ & $2.0 \%$ & 10 \\
& 30 & 20 & $0 \%$ & $0 \%$ & $100 \%$ & $5.0 \%$ & $7.0 \%$ & $2.0 \%$ & 10
\end{tabular}


Some plants have been refurbished since they were first constructed. Rather than use their initial construction year, this refurbishment year was used as the basis for calculating the plant's age. This better models the amount of undepreciated asset remaining. In addition, ongoing capital expenditures are calculated for each year as a simple percentage of the initial cost of the plant, and depreciated over ten years. These costs represent both ongoing capital costs to maintain the plant (over and above fixed O\&M costs) and assets that do not depreciate, such as fuel inventories. The values used ( $2 \%$ of initial construction cost spent each year, depreciated over ten years) mean that the net asset value of the plant never declines below $10 \%$ of the initial capital cost, regardless of age. It may be worthwhile in Phase II to modify these numbers on a plant-by-plant basis to more accurately reflect the actual asset value of the plant, but this would require more information on plant-specific depreciation amounts.

Deferred taxes due to accelerated tax depreciation are also included. All of these factors are used to determine the regulated price of power that each plant would charge to earn their required return on equity. Municipal and coop plants use a debt ratio of almost $100 \%$, lower interest rates, and no taxes to reflect their differing financial status.

From these factors and the construction cost of a plant, a full balance sheet and income statement for any plant can be derived. Table 5 and Table 6 show values for a single $122 \mathrm{MW}$ unit at a gas-fired steam plant that was refurbished in 1990. Note that in this example, the unit only makes $\$ 1,000$ using market-based prices, while its regulated rate of return should provide it with $\$ 712,000$. The plant has a capacity factor of $15 \%$, so it must recoup all of its fixed and variable costs during a limited time of the year when it is producing.

Table 5: Example Balance Sheet for 122 MW gas-fired steam plant refurbished in 1990, M\$

\begin{tabular}{|c|c|c|c|}
\hline \multicolumn{2}{|l|}{ Assets } & \multicolumn{2}{|l|}{ Liabilities } \\
\hline Initial Construction & 19.6 & Debt & 7.3 \\
\hline Capital Expenditures & 3.9 & & \\
\hline Total Gross & 23.5 & & \\
\hline Accum. Depreciation & & Deferred Taxes & 1.4 \\
\hline Initial Construction & 6.2 & & \\
\hline Capital Expenditures & 2.2 & & \\
\hline Total Deprec. & 8.4 & & \\
\hline Net Undepreciated & & Equity & 6.5 \\
\hline Initial Construction & 13.4 & & \\
\hline Capital Expenditures & 1.8 & & \\
\hline Total & 15.1 & Total & 15.1 \\
\hline
\end{tabular}


Table 6: Example Income Statement for 122 MW gas-fired steam plant, M\$

\begin{tabular}{lc} 
Revenue & 8.387 \\
Expenses: & \\
Fuel & 5.418 \\
Variable O\&M & 0.143 \\
Fixed O\&M & $\underline{0.895}$ \\
Net Operating Income & 1.930 \\
$\begin{array}{l}\text { Depreciation } \\
\text { Property Taxes }\end{array}$ & 1.044 \\
Interest & 0.303 \\
Pre-tax Income & $\underline{0.581}$ \\
Income Tax & 0.002 \\
Net Income & 0.001 \\
\hline $\begin{array}{l}\text { Allowed Net Income under } \\
\text { regulated market instead of } \\
\text { restructured market }\end{array}$ & 0.001 \\
&
\end{tabular}

The owners may choose to raise their bid prices in the hopes of securing additional revenue and make a profit. However, in a competitive market, this may mean that they do not operate as often because others have underbid them more frequently. They could end in a losing spiral where, by raising their bid, they operate for less and less time and have a harder time recovering their fixed costs.

The economic optimum for them in a competitive market is to bid their marginal cost. If their bid is the last accepted they neither lose nor gain any funds. If a higher cost plant provides the final accepted bid (and consequent market-clearing price) then they earn profits to offset fixed costs. If the final bid is lower then they do not have to operate at a loss.

In a constrained market during peak times there are few plants available to meet the last increment of demand. The owners of these remaining plants may choose to raise their bids above their marginal cost. These plants become profitable, and all other plants operating during that time receive these high prices as well. If an owner also owns a number of low cost plants, they may even choose to not bid some of their capacity and thereby raise the prices received by their remaining plants.

Customers end up paying very high prices during this time, either instantly if on real-time pricing, or later if billed on average prices. The customers may choose to cut back on demand, which both lowers their overall bill and lowers the peak demand such that more (and lower cost) plants will be competing. These issues of pricing during peak demands, market power, and demand elasticity will be explored during Phase II. 



\section{ORCED Modeling}

The Oak Ridge Competitive Electricity Dispatch (ORCED) model was developed at Oak Ridge National Laboratory to examine numerous facets of a restructured electricity market (Hadley and Hirst 1998). It is an expanded version of a module of an earlier model called ORFIN (Oak Ridge Financial Model) (Hadley 1996). ORFIN is a comprehensive, multi-year utility model that includes T\&D investments but does not calculate the regional market-based price. ORCED deals just with generation for a region but does calculate market-based and regulated generation prices. The model has been used in a variety of studies by different groups across the country:

- Market incentives for adequate generation capacity in a restructured electricity market

- Impact of restructuring on power prices in the Pacific Northwest

- Stranded cost recovery processes in the mid-Atlantic region

- Effect of NOx emission control implementation plans on system reliability

- $\quad$ Potential for economic biomass cofiring on a state and regional basis

- National carbon emissions under differing energy and carbon reducing scenarios

- $\quad$ Effect of carbon taxes on power production in the Midwest

- Benefits of multiple emission controls strategies

- Impacts of hydropower relicensing on carbon emissions

The model itself is a complex Excel spreadsheet that takes the inputs on supply and demand described above and dispatches plants to meet the defined demands for a single year of operation. Optimization routines can be used to determine the optimum mix of plants in a future year depending on constraints and the parameter to be optimized.

Several versions of the model have been developed over the years depending on the needs of the study. For this study we used a version that models a single region without internal transmission constraints. It can handle up to 200 power plants and models two seasons, a peak and an off-peak.

Plant forced outages can be modeled either probabilistically or through derating the plant. When modeled probabilistically, a plant is either available or unavailable, the percentage in each state defined by the forced outage rate. The dispatching of all plants that are more expensive must then be done twice and the results combined based on the probability of the forced outage. Under derating, a plant's total capacity is reduced by the forced outage rate, but the plant is 
available $100 \%$ of the time. Probabilistic modeling is more accurate, but entails an exponential increase in computing time as more plants are treated probabilistically. For this study, the 18 largest plants were treated probabilistically, representing $67 \%$ of available capacity and $74 \%$ of the energy production. Further details on the calculations can be found in the ORCED documentation (Hadley and Hirst 1998).

\subsection{Dispatching}

Once supply and demand are established for the region and data entered in the model, then the plants can be dispatched for each season (Figure 8 and Figure 9). The thick dashed lines represent the original demand load duration curves, the thick lines below them represent the demands after the hydro and pumped storage supplies have been dispatched. The lines with diamonds show the actual dispatch of each plant. Each diamond represents the capacity of an additional plant to meet the demand and the percentage of the period that it runs.

Figure 8 and Figure 9: Peak and off-peak dispatch of plants to meet demand from ORCED
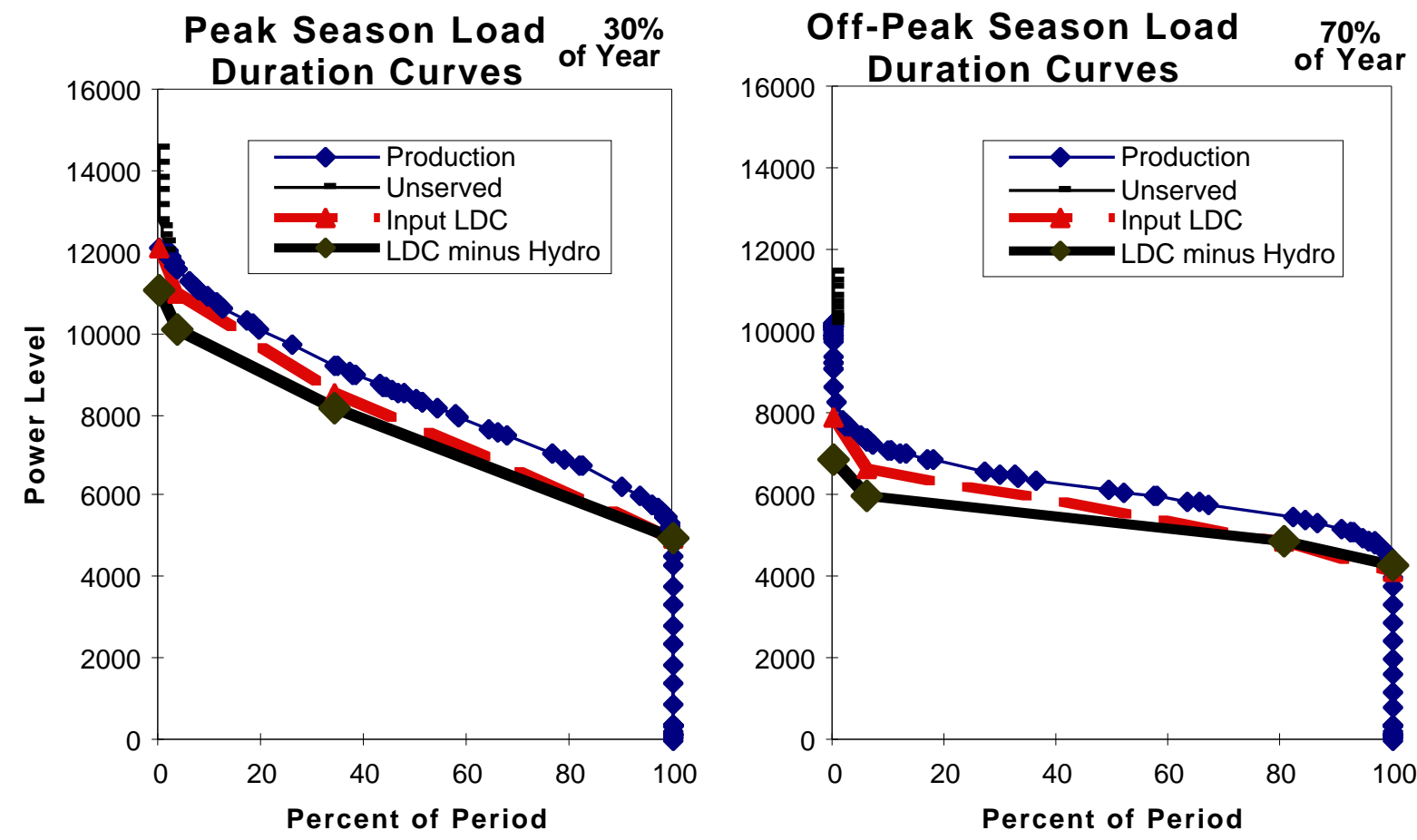

Supply from low-cost plants such as the coal plants and those that are must-run are dispatched first and run $100 \%$ of the time. However, due to forced outages, they are not always available, so plants higher in the loading order must run to both meet demands (the thick lines) but also to compensate for the loss of power from the base load plants. That is why the production lines extend above and to the right of the original demand curves. 


\subsection{Market-Based Pricing}

Each plant is on the margin when its capacity is the top plant being dispatched. The price it charges (its variable and start-up costs ${ }^{1}$ ) is the market-clearing price for that point in time. In a commodity bulk power market, all plants get this price. The revenues that the plant makes are defined by the price during that time period and its production amount. Baseload plants will receive the market-clearing price for the entire period, while mid-level and peaking plants will only receive the higher prices during the peak part of the year they are operating. Figure 10 shows the curve of calculated market prices for the peak and off-peak seasons.

Figure 10: Market prices based on variable costs of last plant dispatched

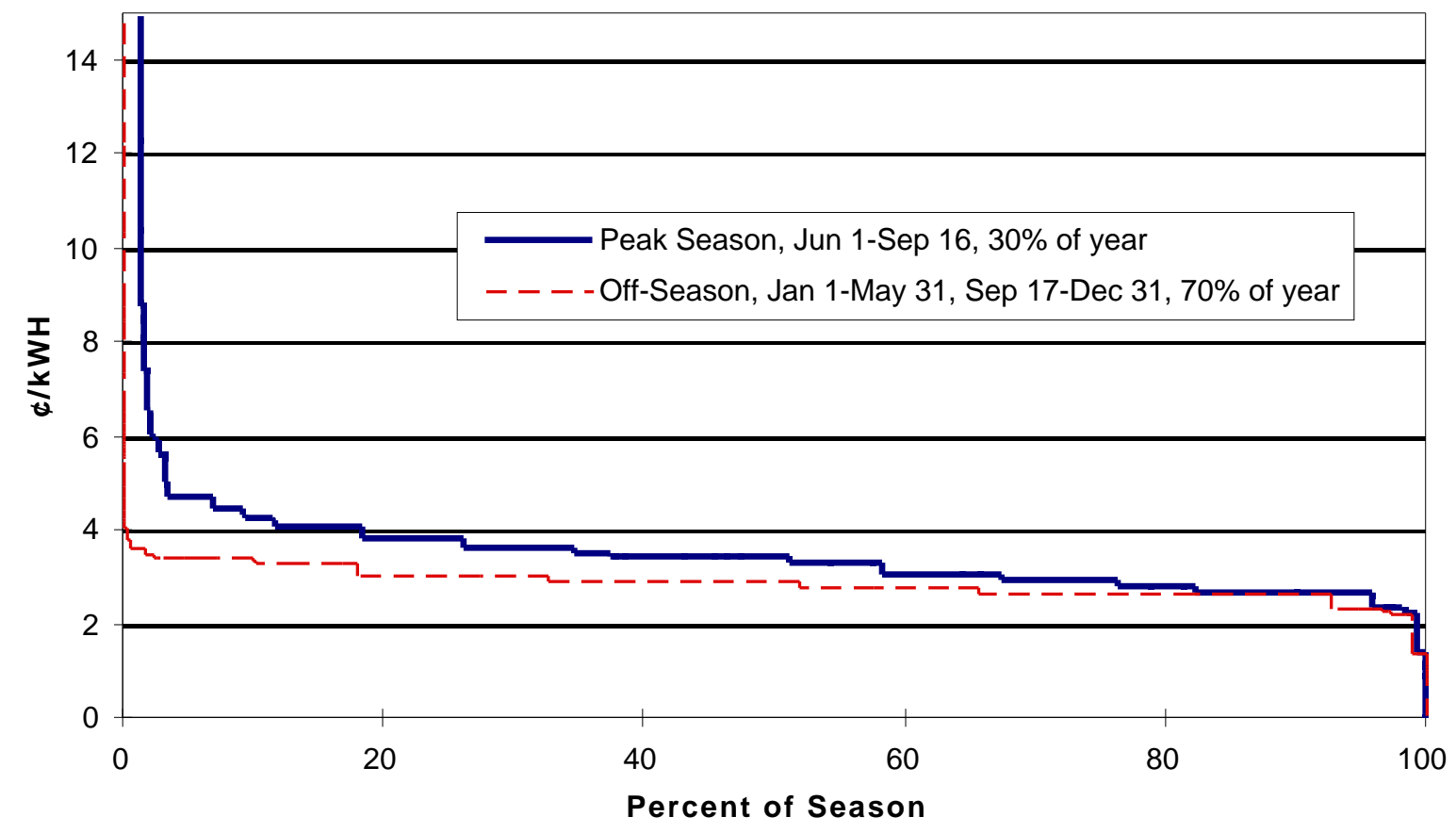

When the last plant in the dispatch order is fully loaded then ORCED calculates prices that are based on a demand-elasticity function. This is used to simulate plants bidding higher than marginal costs thereby lowering demand or unmodeled, emergency generators entering the market at higher prices. When demand exceeds supply (accounting for outages), then a calculation is made using a price elasticity factor to determine the price necessary to reduce demand to the level of available supply. We have used an elasticity value of -0.05 for this portion of demand, resulting in a price during this time of $52 \phi / \mathrm{kWh}$ in the peak season and $29 \phi / \mathrm{kWh}$ in the off-peak season in the base case. These are shown in Figure 10 as the small part of time in each season ( $1.4 \%$ of peak and $0.001 \%$ of off-peak) with the curves off the top of the

\footnotetext{
${ }^{1}$ Start-up costs are estimated based on industry sources at $\$ 40 / \mathrm{MW} /$ startup. These costs are converted to $\phi / \mathrm{kWh}$ based on an estimate of the number of startups and energy generated as a function of capacity factor.
} 
chart. Greater demand elasticity, additional available capacity, or reduced forced outages can lower these values or the percentage of time they apply. For example, wholesale exports may be more price-sensitive and decrease more easily during the high prices. However, the other regions may also be facing constrained supplies and high prices due to high temperatures so may need this power despite the high prices.

The effect of these high prices are most notable on the peaking units since a higher proportion of their sales are during the times of constrained demand. A further exploration of these issues can be found in the Hadley and Hirst report Maintaining Generation Adequacy in a Restructuring U.S. Electricity Industry (Hadley and Hirst 1999).

Customer sales as defined in Figure 5 are multiplied by the marginal price during each point in time. The resulting revenues are paid to each producer based on their production amount during that time. The sum of revenues over both periods defines the total revenues received by a producer. ORCED does not include ancillary services as an additional revenue to plants. In the real world, each plant may earn additional revenue, depending on the ancillary services market and the characteristics of the plant.

\subsection{Regulated Pricing}

Regulated prices are set by determining the total cost of providing power and allocating the costs between customer classes. Total costs are calculated for the sum of all plants over the entire year as shown in Table 7. Fixed costs are largely a function of the installed capital of the facilities. They include fixed O\&M, depreciation, interest charges, taxes, and required return on equity for each plant. Their amounts are assigned to the demand portion of the rate base, to be allocated between customers based on their contribution to the peak demand (Table 8). Variable costs are more a function of the energy produced and so are assigned to the energy portion of the rate base. Those costs are allocated between customers based on their contribution to total energy requirements (Table 9). The allocated demand and energy costs are divided by each customer's demand and energy after losses to determine the price they would pay based on sales at the meter. Residential customers rarely actually pay separate demand and energy rates; instead the demand charge is converted to the equivalent energy charge and added to the energy charge. For reporting purposes, the other customer classes often are treated the same way. This gives prices per kilowatt-hour that each customer must pay.

\section{Table 7: Total Revenue Requirements under regulated pricing}

\begin{tabular}{lr} 
& Fixed Costs \\
O\&M & 119.10 \\
Non-Equity & 343.24 \\
Return on Equity + taxes & 86.26 \\
$\quad$ Variable Costs \\
Fuel & 830.36 \\
Other variable & 87.71 \\
\hline \multicolumn{2}{r}{ Total } \\
\end{tabular}


Table 8: Regulated demand charge calculation

\begin{tabular}{l|cccc} 
& MW at Busbar & Percent of Total & MW at meter & Demand Charge, $\mathbf{\$} \mathbf{k W}$ \\
\hline Residential & 5,882 & $48 \%$ & 5,412 & 49.14 \\
Commercial & 2,525 & $21 \%$ & 2,373 & 48.10 \\
Industrial & 2,489 & $21 \%$ & 2,365 & 47.59 \\
Other & 1,237 & $10 \%$ & 1,163 & 48.10 \\
Total & 12,134 & $100 \%$ & &
\end{tabular}

Table 9: Regulated energy charge calculation

\begin{tabular}{l|ccccc} 
& GWh at Busbar & Percent & GWh at meter & $\begin{array}{c}\text { Energy Charge } \\
\mathbf{C / k W h}\end{array}$ & $\begin{array}{c}\text { Combined Price } \\
\mathbf{C / k W h}\end{array}$ \\
\hline Residential & 19,893 & $36 \%$ & 18,301 & 1.81 & 3.26 \\
Commercial & 13,190 & $24 \%$ & 12,398 & 1.77 & 2.69 \\
Industrial & 13,970 & $25 \%$ & 13,271 & 1.75 & 2.60 \\
Other & 8,088 & $15 \%$ & 7,603 & 1.77 & 2.51 \\
\cline { 2 - 3 } Total & 55,140 & $100 \%$ & & &
\end{tabular}

\subsection{Total Retail Price}

The calculations within ORCED only include the generation costs. To find the total prices including T\&D and customer services, the current regulated prices must be separated into their generation and non-generation components. The 1999 total price for each customer class can be found by dividing the total retail revenues for each class by the retail sales for each class (RDI 2001). The generation portion is calculated within ORCED based on the cost of production plus fixed costs, as described above. Subtracting the generation-related price from the total gives the T\&D components for each class. Since these components are expected to continue to be regulated, their prices were kept constant in both the regulated and restructured cases. 



\section{Results}

This section reports the difference in prices between the regulated and restructured market. It shows the consequences of these prices on the total bills that customers would pay, and that producers would receive. Sensitivities were run to show the impacts of varying certain parameters.

\subsection{Regulated Versus Market Prices}

Prices in the deregulated market will fluctuate hourly throughout the year, following the marginal cost of the last plant operating. Figure 10 shows the price curve for each season of the year. Note that in the peak summer months demand is higher causing prices to be higher for a larger percentage of the time.

Average regulated and market-based prices, as calculated within ORCED, are shown in Table 10. Total rates for 1999 can be found from data submissions to FERC that are contained in the Powerdat database. Subtracting the calculated regulated generation rates from the total rates for 1999, we can determine the transmission \& distribution portion of the rates. Because T\&D continues to be regulated, these rates will stay the same in the regulated and market scenarios. The next column shows the average rates for each customer class using the marginal prices from Figure 10. Their demands, as shown in Figure 5, are multiplied by the prices for each point in time. Residential customers have proportionately more of their purchases made during the high priced time of the year than other customers do. As a consequence, their average market-based price is higher than for the other customers. Similarly, their load factor (ratio of average use to maximum use) is lower so that their proportion of the capacity-related costs is higher. This increases their regulated generation price.

Table 10: Average regulated and market prices, $\phi / \mathrm{kWh}$

\begin{tabular}{l|cccccc} 
& $\begin{array}{c}\text { 1999 Avg. } \\
\text { Price }\end{array}$ & $\begin{array}{c}\text { Regulated } \\
\text { Generation }\end{array}$ & T\&D & $\begin{array}{c}\text { Market-based } \\
\text { Generation }\end{array}$ & $\begin{array}{c}\text { Total for } \\
\text { Restructure }\end{array}$ & Difference \\
\hline Residential & 6.60 & 3.27 & 3.33 & 4.07 & 7.40 & 0.80 \\
Commercial & 5.58 & 2.70 & 2.88 & 3.69 & 6.57 & 0.99 \\
Industrial & 3.60 & 2.61 & 1.00 & 3.60 & 4.59 & 0.99 \\
Other & 4.80 & 2.51 & 2.29 & 3.58 & 5.88 & 1.07
\end{tabular}

Adding the market-based generation prices and $T \& D$ prices for each class gives the average price paid (Figure 11). This can be compared against the regulated price to show the increase (or decrease) due to restructuring. In this analysis, residential customers see a price increase of 0.8 $\phi / \mathrm{kWh}$, while commercial and industrial customers have an increase of $1.0 \phi / \mathrm{kWh}$. 
Figure 11: 1999 retail prices and calculated market-based prices for each customer class. The T\&D component is constant in both scenarios.

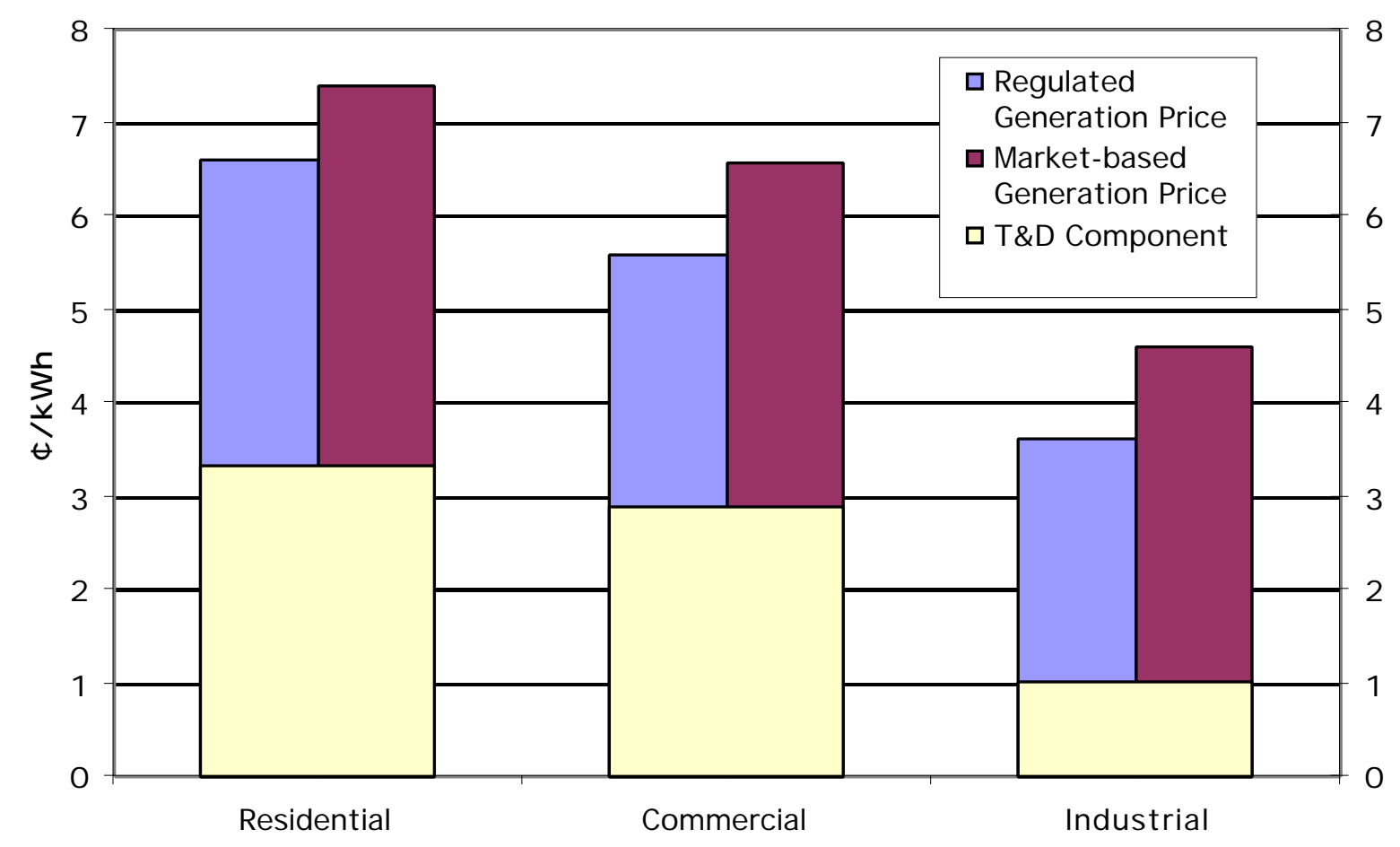

\subsection{Impacts on Customers}

As a consequence of the price changes customer bills would go up between $12 \%$ and $28 \%$ (Table 11). Not all of these increases would be at the expense of Oklahoma consumers, since the Other category includes some sales on the wholesale market.

Table 11: Total electricity bill to consumers, M\$

\begin{tabular}{l|cccc} 
Total Bill & Regulated & Market & Difference & $\%$ Increase \\
\hline Residential & 1,208 & 1,356 & 148 & $12 \%$ \\
Commercial & 692 & 816 & 124 & $18 \%$ \\
Industrial & 478 & 610 & 132 & $28 \%$ \\
Other & 365 & 447 & 82 & $22 \%$ \\
\cline { 2 - 4 } Total & 2,743 & 3,229 & 486 & $18 \%$
\end{tabular}

\subsection{Financial Impacts on Production}

The first two columns of Table 12 show the capacity and production for each plant type. Dividing the production in MWyr by the capacity in MW shows the capacity factor of each plant type (Table 14). The remaining columns are in millions of dollars and show the revenues and costs under a restructured market. Variable and startup costs include fuel, variable operations, and any $\mathrm{SO}_{2}$ permits required (priced at $\$ 200 /$ ton). Non-equity capital related costs include 
depreciation, interest, and property taxes, if applicable. Pre-tax income is the difference between revenues and costs. This amount is multiplied by the income tax rate with the remainder being Net Income. The last column shows the amount of net income that would be expected under a regulatory environment, based on the allowed return on equity.

Coal_L is the sum of low-sulfur coal-fired plants while Coal_S is the sum of all scrubbed coal-fired plants. CC stands for combined cycle plants; CT for combustion turbines, and ST for steam plants. The plant types with an "M-" in front are must-run plants owned by non-utilities that sell some fraction of their power on the grid. There is some additional non-utility generation in the state, but its production is used as cogeneration and little of the power is sold on the grid. "P. Stor" represents pumped storage capacity, which purchases power at low cost times and resells at high cost times.

Table 12: Financial results for each plant type, $M \$$

\begin{tabular}{|c|c|c|c|c|c|c|c|c|c|c|}
\hline \multirow{2}{*}{$\begin{array}{l}\text { Plant } \\
\text { type }\end{array}$} & \multirow{2}{*}{$\begin{array}{l}\text { Capa- } \\
\text { city } \\
\text { MW }\end{array}$} & \multirow{2}{*}{$\begin{array}{l}\text { Output } \\
\text { MWyr }\end{array}$} & \multicolumn{7}{|c|}{ Restructured Market Finances } & \multirow{2}{*}{ 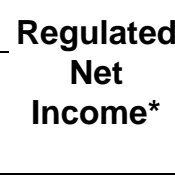 } \\
\hline & & & Revenue & $\begin{array}{l}\text { Var.t } \\
\text { Start } \\
\text { Cost }\end{array}$ & $\begin{array}{l}\text { Fixed } \\
\text { O\&M } \\
\text { Cost }\end{array}$ & $\begin{array}{l}\text { Non- } \\
\text { Equity } \\
\text { Capital }\end{array}$ & $\begin{array}{l}\text { Pre-Tax } \\
\text { Income }\end{array}$ & $\begin{array}{c}\text { Income } \\
\text { Taxes }\end{array}$ & $\begin{array}{c}\text { Net } \\
\text { Income }\end{array}$ & \\
\hline Coal_L & 4,348 & 3,244 & 931 & 303 & 48 & 147 & 434 & 134 & 300 & 17 \\
\hline Coal_S & 520 & 364 & 105 & 36 & 6 & 35 & 27 & 0 & 27 & 0 \\
\hline Gas CC & 766 & 446 & 135 & 90 & 7 & 9 & 28 & 6 & 23 & 1 \\
\hline Gas CT & 505 & 60 & 27 & 15 & 2 & 9 & 1 & -0 & 1 & 2 \\
\hline Gas ST & 5,707 & 1,486 & 544 & 382 & 34 & 93 & 34 & 13 & 22 & 36 \\
\hline Hydro & 775 & 304 & 103 & 5 & 12 & 12 & 74 & 0 & 74 & 0 \\
\hline M-Coal & 287 & 260 & 74 & 29 & 4 & 22 & 19 & 0 & 19 & 0 \\
\hline M-Gas & 146 & 129 & 36 & 33 & 1 & 4 & -1 & 0 & -1 & 0 \\
\hline Oil CT & 30 & 0.15 & 0.58 & 0.10 & 0.09 & 0.17 & 0.23 & 0.06 & 0.16 & 0.03 \\
\hline \multirow[t]{2}{*}{ P. Stor } & 260 & $0^{* *}$ & 9 & 4 & 4 & 13 & -12 & 0 & -12 & 0 \\
\hline & 13,344 & 6,293 & 1,965 & 898 & 119 & 343 & 605 & 152 & 452 & 55 \\
\hline
\end{tabular}

* Regulated net income for municipal- and cooperative-owned plants is zero since debt-financed.

** Pumped storage generates 16 MWyr but also consumes 16 MWyr, assuming $100 \%$ efficiency

Because of the change in pricing from regulated to market based, most plants make significantly more net income under restructuring than under a regulated environment. Low sulfur coal plants make $\$ 300$ million under market-based rates, whereas under regulated rates they would have a net income of $\$ 17$ million (Figure 12). Similarly, scrubbed coal, gas combined cycle, and hydro plants earn significantly more than their regulated rate of return. On the other hand, gas-fired steam plants, combustion turbines, and pumped storage plants earn less than under regulated rates. Under regulated rates, plants owned by cooperatives and municipals have no net income since they are debt-financed. The pumped storage facility loses money under market-based rates because we used a capacity factor of $6 \%$, based on historical operations. While it recovers its O\&M costs, it does not recover the capital costs as calculated by ORCED.

Another way to represent the financial results is in terms of cents/kWh (Table 13 and Figure 13). The revenue per kilowatt-hour for the baseload plants reflects the average price over the full year. Plants that are mid-level or peakers receive higher average prices since they operate only during the higher priced times of the year. However, they also have higher costs per $\mathrm{kWh}$, both the variable costs and fixed costs. Variable costs are higher since that is mainly what defines 
them as peakers; fixed costs are higher because of fewer kWh over which to spread the costs. Capacity factors are shown in Table 14 . Figure 13 just shows the major plant types to avoid the extremes from Oil CT's, hydro, must-run units, and pumped storage.

\section{Figure 12: Net income for different plant types under market-based and regulated prices}

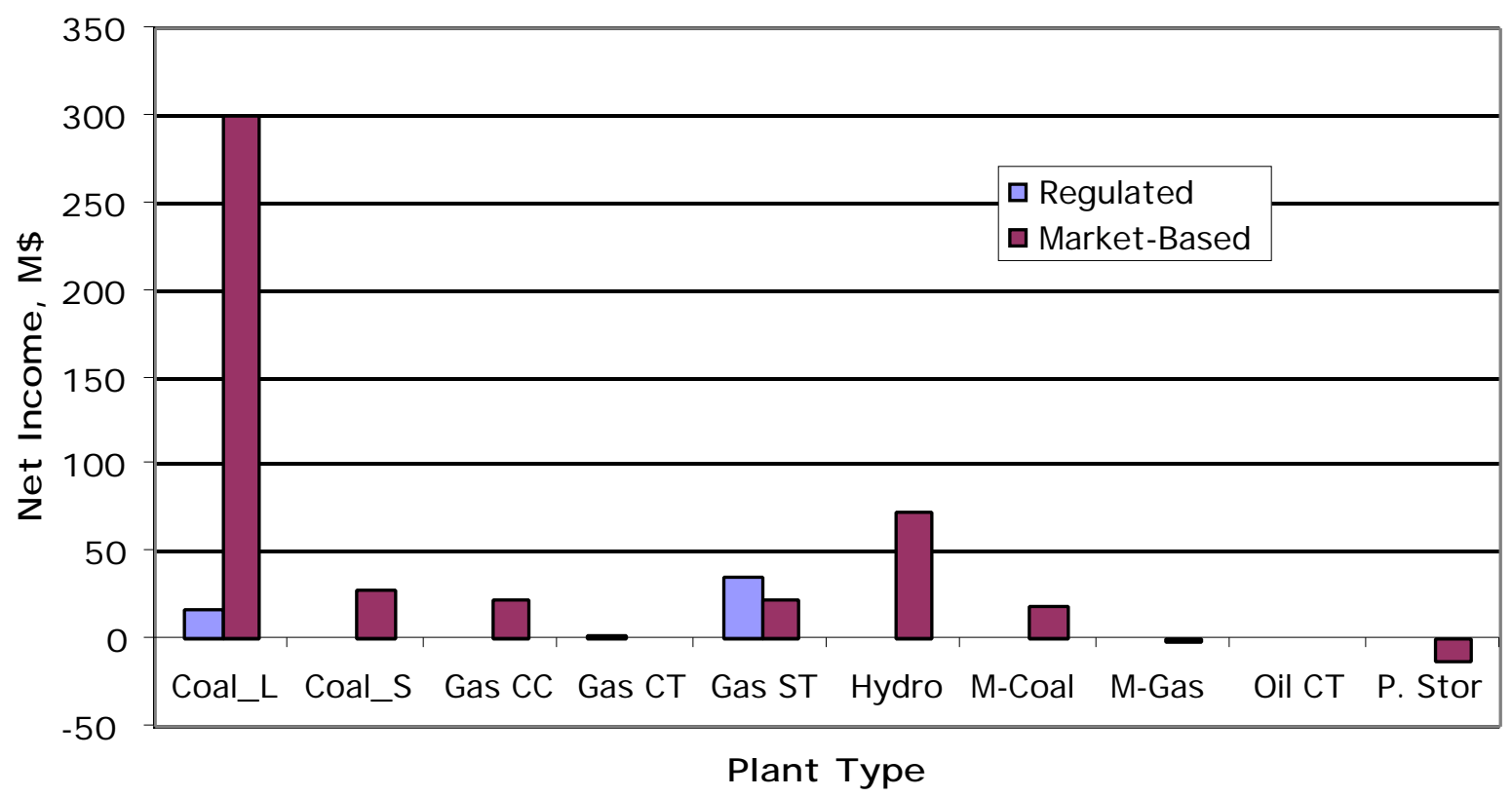

Table 13: Market finances for plant types in cents/kWh

\begin{tabular}{|c|c|c|c|c|c|c|c|c|c|c|}
\hline \multirow{2}{*}{$\begin{array}{l}\text { Plant } \\
\text { type }\end{array}$} & \multirow{2}{*}{$\begin{array}{l}\text { Capa- } \\
\text { city } \\
\text { MW }\end{array}$} & \multirow{2}{*}{$\begin{array}{l}\text { Output } \\
\text { MWyr }\end{array}$} & \multicolumn{7}{|c|}{ Restructured Market Finances, $\mathbf{c} / \mathbf{k W h}$} & \multirow{2}{*}{$\begin{array}{c}\text { Regulated } \\
\text { Net } \\
\text { Income, } \\
\mathbf{c} / \mathbf{k W h}^{\star}\end{array}$} \\
\hline & & & Revenue & $\begin{array}{l}\text { Var.+ } \\
\text { Start } \\
\text { Cost }\end{array}$ & $\begin{array}{l}\text { Fixed } \\
\text { O\&M } \\
\text { Cost }\end{array}$ & $\begin{array}{l}\text { Non- } \\
\text { Equity } \\
\text { Capital }\end{array}$ & $\begin{array}{l}\text { Pre-Tax } \\
\text { Income }\end{array}$ & $\begin{array}{c}\text { Income } \\
\text { Taxes }\end{array}$ & $\begin{array}{c}\text { Net } \\
\text { Income }\end{array}$ & \\
\hline Coal_L & 4,348 & 3,244 & 3.28 & 1.06 & 0.17 & 0.52 & 1.53 & 0.47 & 1.06 & 0.06 \\
\hline Coal_S & 520 & 364 & 3.28 & 1.13 & 0.20 & 1.09 & 0.86 & 0.00 & 0.86 & 0.00 \\
\hline Gas CC & 766 & 446 & 3.45 & 2.31 & 0.18 & 0.23 & 0.73 & 0.14 & 0.58 & 0.02 \\
\hline Gas CT & 505 & 60 & 5.09 & 2.82 & 0.40 & 1.70 & 0.16 & -0.02 & 0.19 & 0.30 \\
\hline Gas ST & 5,707 & 1,486 & 4.18 & 2.94 & 0.26 & 0.72 & 0.26 & 0.10 & 0.17 & 0.27 \\
\hline Hydro & 775 & 304 & 3.88 & 0.20 & 0.46 & 0.45 & 2.77 & 0.00 & 2.77 & 0.00 \\
\hline M-Coal & 287 & 260 & 3.24 & 1.25 & 0.18 & 0.96 & 0.84 & 0.00 & 0.84 & 0.00 \\
\hline M-Gas & 146 & 129 & 3.24 & 2.96 & 0.05 & 0.36 & -0.13 & 0.00 & -0.13 & 0.00 \\
\hline Oil CT & 30 & 0 & 45.02 & 7.91 & 6.61 & 12.86 & 17.64 & 5.00 & 12.64 & 2.03 \\
\hline \multirow[t]{2}{*}{ P. Stor } & 260 & $0^{\star *}$ & 6.58 & 3.29 & 3.10 & 9.15 & -8.95 & 0.00 & -8.95 & 0.00 \\
\hline & 13,344 & 6,293 & 3.56 & 1.63 & 0.22 & 0.62 & 1.10 & 0.28 & 0.82 & 0.10 \\
\hline
\end{tabular}

${ }^{*}$ Regulated net income for municipal- and cooperative-owned plants is zero since debt-financed.

** Pumped storage generates $16 \mathrm{MWyr}$ but also consumes $16 \mathrm{MWyr}$, assuming $100 \%$ efficiency

Some of the Oil CT plants operate at the very peak of demand. They receive their marginal cost while they are on the margin and the demand elasticity driven prices while fully loaded, as described in section 4.2. Because their revenues are dominated by the period of time when 
demand exceeds supply, their revenue per $\mathrm{kWh}$, and consequent net income, is quite high. All other plants receive these prices during this same time, but are less affected because the time these prices are available is a lesser percentage of their overall operating time. However, for peaking plants the price during this time can mean the difference between an overall profit and loss for the year.

Figure 13: Net income per $\mathrm{kWh}$ for plant types under market-based and regulated pricing

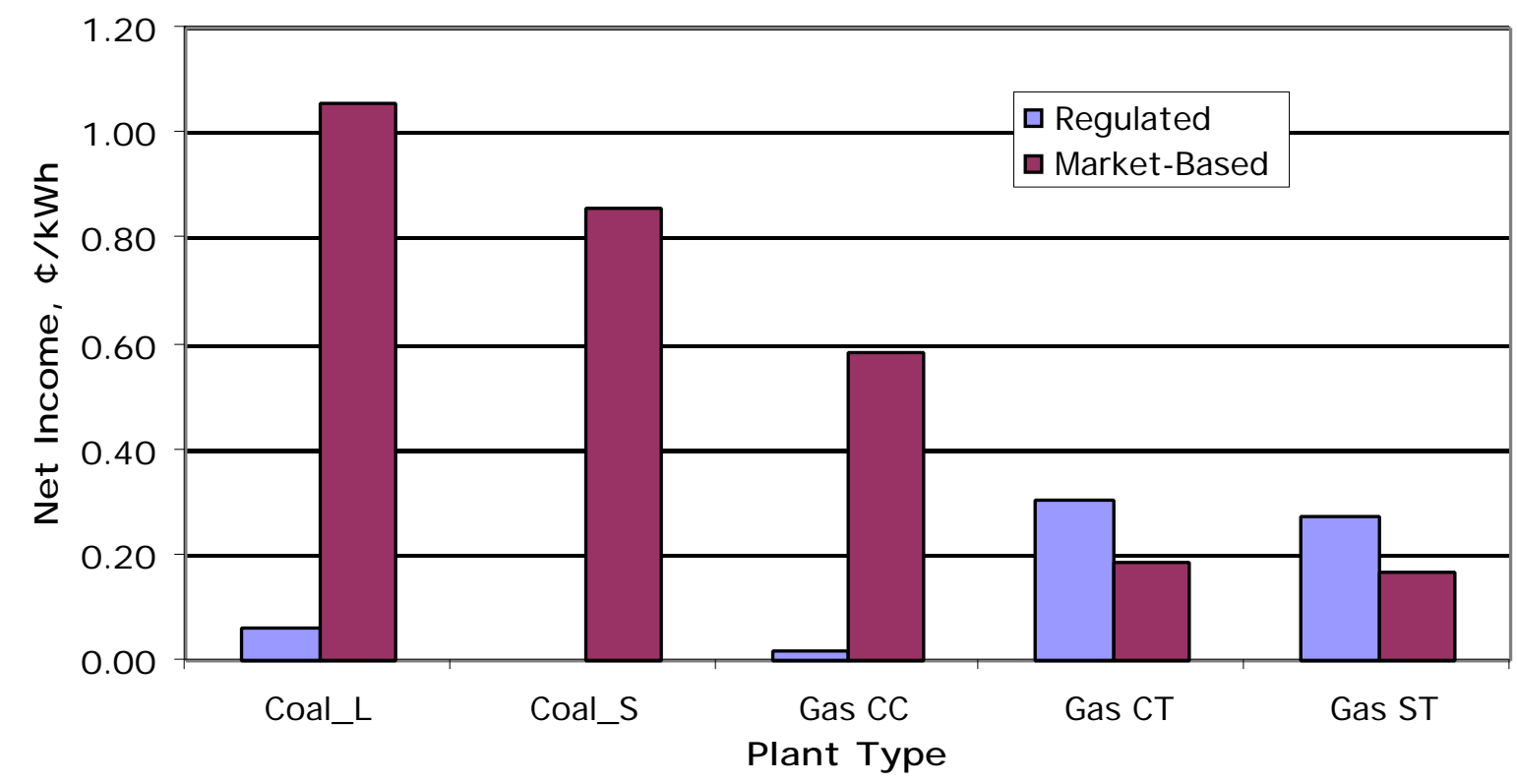

Gas-fired production (either combined cycle, steam, or combustion turbine) is the marginal producer $99 \%$ of the time (Table 14). Consequently, coal plants receive prices based on the much higher variable cost of natural gas rather than their own costs. If prices were to decline to be in line with coal production costs, then gas-fired production would be operating at a loss.

Table 14: Operating results by plant type

\begin{tabular}{l|rrrrrr} 
Plant Type & $\begin{array}{c}\text { Capacity } \\
\text { MW }\end{array}$ & $\begin{array}{c}\text { \% of Total } \\
\text { Generation } \\
\text { MWyr }\end{array}$ & $\begin{array}{c}\text { \% of Total Capacity Factor Time on Margin } \\
\%\end{array}$ \\
\hline Coal_L & 4,348 & 33 & 3,244 & 52 & 75 & 1 \\
Coal_S & 520 & 4 & 364 & 6 & 70 & 0 \\
Gas CC & 766 & 6 & 446 & 7 & 58 & 6 \\
Gas CT & 505 & 4 & 60 & 1 & 12 & 3 \\
Gas ST & 5,707 & 43 & 1,486 & 24 & 26 & 90 \\
Hydro & 775 & 6 & 304 & 5 & 39 & 0 \\
M-Coal & 287 & 2 & 260 & 4 & 90 & 0 \\
M-Gas & 146 & 1 & 129 & 2 & 88 & 0 \\
Oil CT & 30 & 0 & 0 & 0 & 0 & 0 \\
P. Stor & 260 & 2 & $0^{*}$ & 0 & 0 &
\end{tabular}

*Pumped storage generates $16 \mathrm{MWyr}$ but also consumes $16 \mathrm{MWyr}$, assuming $100 \%$ efficiency 


\subsection{Sensitivities}

\subsubsection{Higher Gas Prices}

The analysis described above is based largely on data from 1999. Today's gas prices are significantly higher than 1999. What is the impact on prices, both regulated and market-based, if gas prices rise? To examine this, we raised the average gas price from $\$ 2.76 / \mathrm{MBtu}$, the weighted average price for the base case, to $\$ 4.13 / \mathrm{MBtu}$, the average price paid by Oklahoma utilities through September 2000 according to EIA's Natural Gas Monthly (EIA 2001). Note that in ORCED each plant pays a separate price for their fuel, based upon the actual data. Raising the average price will raise the prices that each pay based on the ratio of the new average price to the original average price.

The resulting price changes are shown in Table 15 and Figure 14. Market-based prices rise more dramatically than the regulated prices. Since gas-fired production is on the margin and sets the price almost $99 \%$ of the time, increases in gas prices will cause almost a one for one increase in marginal generation prices. A 53\% increase in gas prices raises market-based generation prices about $40 \%$ (Table 16). The overall price increases are somewhat tempered by the T\&D price, which is constant; total prices increase between $21 \%$ and $33 \%$ from the base case.

Table 15: Regulated and market prices with higher natural gas prices, $\phi / \mathrm{kWh}$

\begin{tabular}{l|cccccc} 
& T\&D & $\begin{array}{c}\text { Regulated } \\
\text { Generation } \\
\text { Price }\end{array}$ & $\begin{array}{c}\text { Total Regulated } \\
\text { Price }\end{array}$ & $\begin{array}{c}\text { Restructured } \\
\text { Generation } \\
\text { Price }\end{array}$ & $\begin{array}{c}\text { Total } \\
\text { Restructured } \\
\text { Price }\end{array}$ & $\begin{array}{c}\text { Differ- } \\
\text { ence }\end{array}$ \\
\hline Residential & 3.34 & 3.75 & 7.09 & 5.65 & 8.99 & 1.90 \\
Commercial & 2.89 & 3.17 & 6.06 & 5.22 & 8.11 & 2.05 \\
Industrial & 1.00 & 3.07 & 4.08 & 5.09 & 6.10 & 2.02 \\
Other & 2.30 & 2.99 & 5.28 & 5.10 & 7.39 & 2.11
\end{tabular}

Regulated prices are less sensitive because they are based on the cost of all fuels rather than the fuel on the margin. Their generation price rises between $15 \%$ and $19 \%$. They too are tempered by the constant T\&D prices so that the total regulated prices only increase between $7 \%$ and $13 \%$, depending on customer class.

Table 16: Percentage price increases of high gas price case over base case

\begin{tabular}{l|ccccc} 
& T\&D & $\begin{array}{c}\text { Regulated } \\
\text { Generation Price }\end{array}$ & $\begin{array}{c}\text { Total Regulated } \\
\text { Price }\end{array}$ & $\begin{array}{c}\text { Restructured } \\
\text { Generation Price }\end{array}$ & $\begin{array}{c}\text { Total Restructured } \\
\text { Price }\end{array}$ \\
\hline Residential & $0 \%$ & $15 \%$ & $7 \%$ & $39 \%$ & $21 \%$ \\
Commercial & $0 \%$ & $18 \%$ & $9 \%$ & $41 \%$ & $23 \%$ \\
Industrial & $0 \%$ & $18 \%$ & $13 \%$ & $42 \%$ & $33 \%$ \\
Other & $0 \%$ & $19 \%$ & $10 \%$ & $42 \%$ & $26 \%$
\end{tabular}


Figure 14: Regulated and market-based customer prices from the base case and with high gas prices

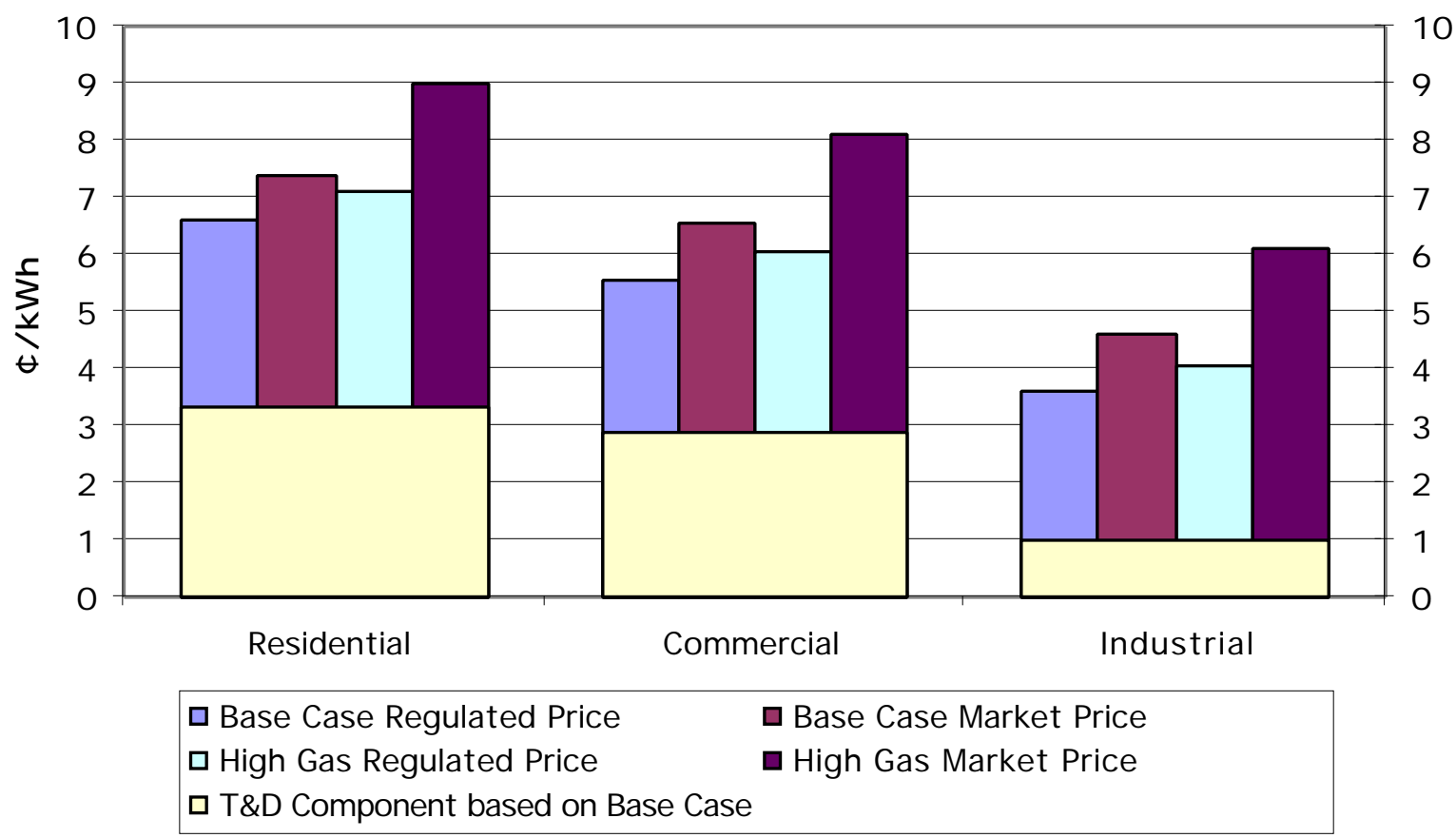

Coal plants earn much more with high gas prices, since their costs are not affected but their revenues increase (Table 17 and Figure 15). Under regulated prices, their net income remains the same as in the base case. All plant types see improvement in earnings, since prices increase more rapidly as the least efficient gas-fired plants come on the margin and set a higher price.

Table 17: Power plant financial results with high gas prices, M\$

\begin{tabular}{|c|c|c|c|c|c|c|c|c|c|c|}
\hline \multirow{2}{*}{$\begin{array}{l}\text { Plant } \\
\text { type }\end{array}$} & \multirow{2}{*}{$\begin{array}{c}\text { Capa- } \\
\text { city } \\
\text { MW }\end{array}$} & \multirow{2}{*}{$\begin{array}{l}\text { Output } \\
\text { MWyr }\end{array}$} & \multicolumn{7}{|c|}{ Restructured Market Finances } & \multirow{2}{*}{$\begin{array}{c}\text { Regulated } \\
\text { Net } \\
\text { Income }\end{array}$} \\
\hline & & & Revenue & $\begin{array}{l}\text { Var.+ } \\
\text { Start } \\
\text { Cost }\end{array}$ & $\begin{array}{l}\text { Fixed } \\
\text { O\&M } \\
\text { Cost }\end{array}$ & $\begin{array}{l}\text { Non- } \\
\text { Equity } \\
\text { Capital }\end{array}$ & $\begin{array}{l}\text { Pre-Tax } \\
\text { Income }\end{array}$ & $\begin{array}{c}\text { Income } \\
\text { Taxes }\end{array}$ & $\begin{array}{c}\text { Net } \\
\text { Income }\end{array}$ & \\
\hline Coal_L & 4,348 & 3,244 & 1,332 & 303 & 48 & 147 & 835 & 249 & 586 & 17 \\
\hline Coal's & 520 & 364 & 149 & 36 & 6 & 35 & 72 & 0 & 72 & 0 \\
\hline Gas $\bar{C} c$ & 766 & 462 & 198 & 141 & 7 & 9 & 42 & 8 & 34 & 1 \\
\hline Gas CT & 505 & 59 & 34 & 21 & 2 & 9 & 2 & 0 & 2 & 2 \\
\hline Gas ST & 5,707 & 1,470 & 734 & 557 & 34 & 93 & 50 & 17 & 33 & 36 \\
\hline Hydro- & 775 & 304 & 144 & 5 & 12 & 12 & 114 & 0 & 114 & 0 \\
\hline M-Coal & 287 & 260 & 106 & 29 & 4 & 22 & 51 & 0 & 51 & 0 \\
\hline M-Gas & 146 & 129 & 52 & 48 & 1 & 4 & 0 & 0 & 0 & 0 \\
\hline Oil CT & 30 & 2 & 1 & 1 & 0 & 0 & 0 & 0 & 0 & 0 \\
\hline \multirow[t]{2}{*}{ P. Stor } & 260 & 0 & 11 & 6 & 4 & 13 & -12 & 0 & -12 & 0 \\
\hline & 13,344 & 6,293 & 2,761 & 1,146 & 119 & 343 & 1,153 & 273 & 880 & 55 \\
\hline
\end{tabular}


Figure 15: Net income for plant types with market-based and regulated prices, including market prices with higher natural gas prices

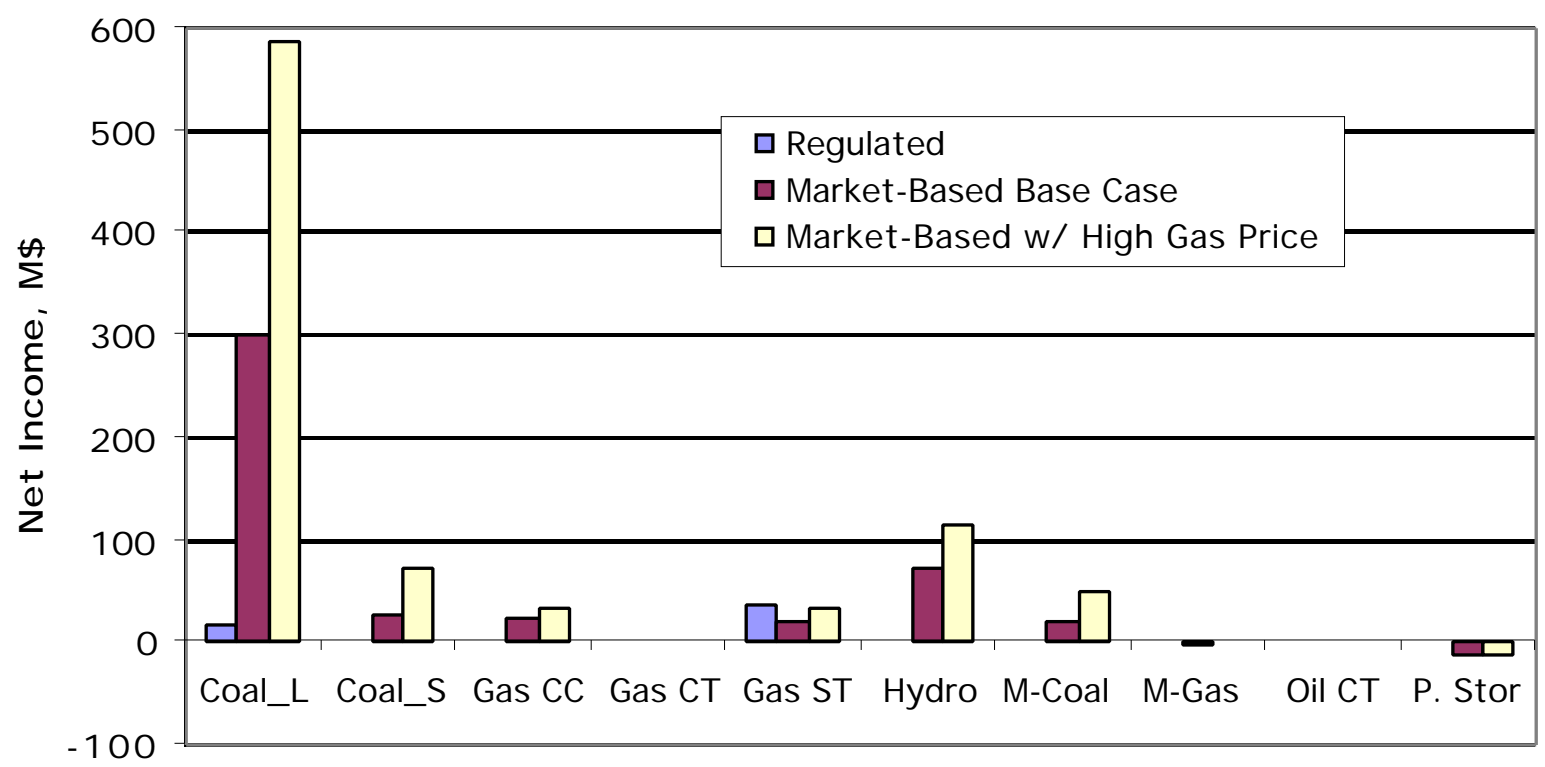

Plant Type

As in the base case, the financial results can be shown in terms of $\phi / \mathrm{kWh}$ (Table 18 and Figure 16). Coal revenues, and consequent net income, rise to over two cents per kWh beyond what regulated prices would provide. Coal_S net income increases the most because the lack of income taxes (since all of its plants are owned by a cooperative or public utility) passes all increased revenues to the utility. Even gas-fired generation net income rises. Oil CT plants in general move down in the loading order and are dispatched more often, so their revenue per $\mathrm{kWh}$ declines from the high values in the base case.

Table 18: Market finances for plant types in cents/kWh for high gas price sensitivity

\begin{tabular}{|c|c|c|c|c|c|c|c|c|c|c|}
\hline \multirow{2}{*}{$\begin{array}{l}\text { Plant } \\
\text { type }\end{array}$} & \multirow{2}{*}{$\begin{array}{l}\text { Capa- } \\
\text { city } \\
\text { MW }\end{array}$} & \multirow{2}{*}{$\begin{array}{l}\text { Output } \\
\text { Mwyr }\end{array}$} & \multicolumn{7}{|c|}{ Restructured Market Finances, c/kWh } & \multirow{2}{*}{$\begin{array}{c}\text { Regulated } \\
\text { Net } \\
\text { Income, } \\
\text { c/kWh* }\end{array}$} \\
\hline & & & Revenue & $\begin{array}{l}\text { Var.+ } \\
\text { Start } \\
\text { Cost }\end{array}$ & $\begin{array}{l}\text { Fixed } \\
\text { O\&M } \\
\text { Cost }\end{array}$ & $\begin{array}{l}\text { Non- } \\
\text { Equity } \\
\text { Capital }\end{array}$ & $\begin{array}{l}\text { Pre-Tax } \\
\text { Income }\end{array}$ & $\begin{array}{c}\text { Income } \\
\text { Taxes }\end{array}$ & $\begin{array}{c}\text { Net } \\
\text { Income }\end{array}$ & \\
\hline Coal_L & 4,348 & 3,244 & 4.69 & 1.06 & 0.17 & 0.52 & 2.94 & 0.87 & 2.06 & 0.06 \\
\hline Coal_s & 520 & 364 & 4.69 & 1.13 & 0.20 & 1.09 & 2.26 & 0.00 & 2.26 & 0.00 \\
\hline Gas CC & 766 & 462 & 4.90 & 3.48 & 0.18 & 0.22 & 1.03 & 0.19 & 0.84 & 0.02 \\
\hline Gas CT & 505 & 59 & 6.59 & 4.06 & 0.41 & 1.75 & 0.37 & -0.04 & 0.41 & 0.31 \\
\hline Gas ST & 5,707 & 1,470 & & 4.32 & 0.27 & 0.73 & 0.39 & 0.13 & 0.2 & 0.28 \\
\hline Hydro & 775 & 304 & 5.39 & 0.20 & 0.46 & 0.45 & 4.28 & 0.00 & 4.28 & 0.00 \\
\hline M-Coal & 287 & 260 & 4.64 & 1.25 & 0.18 & 0.96 & 2.25 & 0.00 & 2.25 & 0.00 \\
\hline M-Gas & 146 & 129 & 4.64 & 4.28 & 0.05 & 0.36 & -0.04 & 0.00 & -0.04 & 0.00 \\
\hline Oil CT & 30 & 2 & 8.66 & 4.80 & 0.57 & 1.11 & 2.18 & 0.66 & 1.51 & 0.18 \\
\hline \multirow[t]{2}{*}{ P. Stor } & 260 & $0^{* *}$ & 8.10 & 4.47 & 3.10 & 9.15 & -8.62 & 0.00 & -8.62 & 0.00 \\
\hline & 13,344 & 6,293 & 5.01 & 2.08 & 0.22 & 0.62 & 2.09 & 0.50 & 1.60 & 0.10 \\
\hline
\end{tabular}

${ }^{*}$ Regulated net income for municipal- and cooperative-owned plants is zero since debt-financed.

** Pumped storage generates $16 \mathrm{MWyr}$ but also consumes $16 \mathrm{MWyr}$, assuming $100 \%$ efficiency 
Figure 16: Net income for plant types in cents/kWh for base case and high gas price sensitivity case

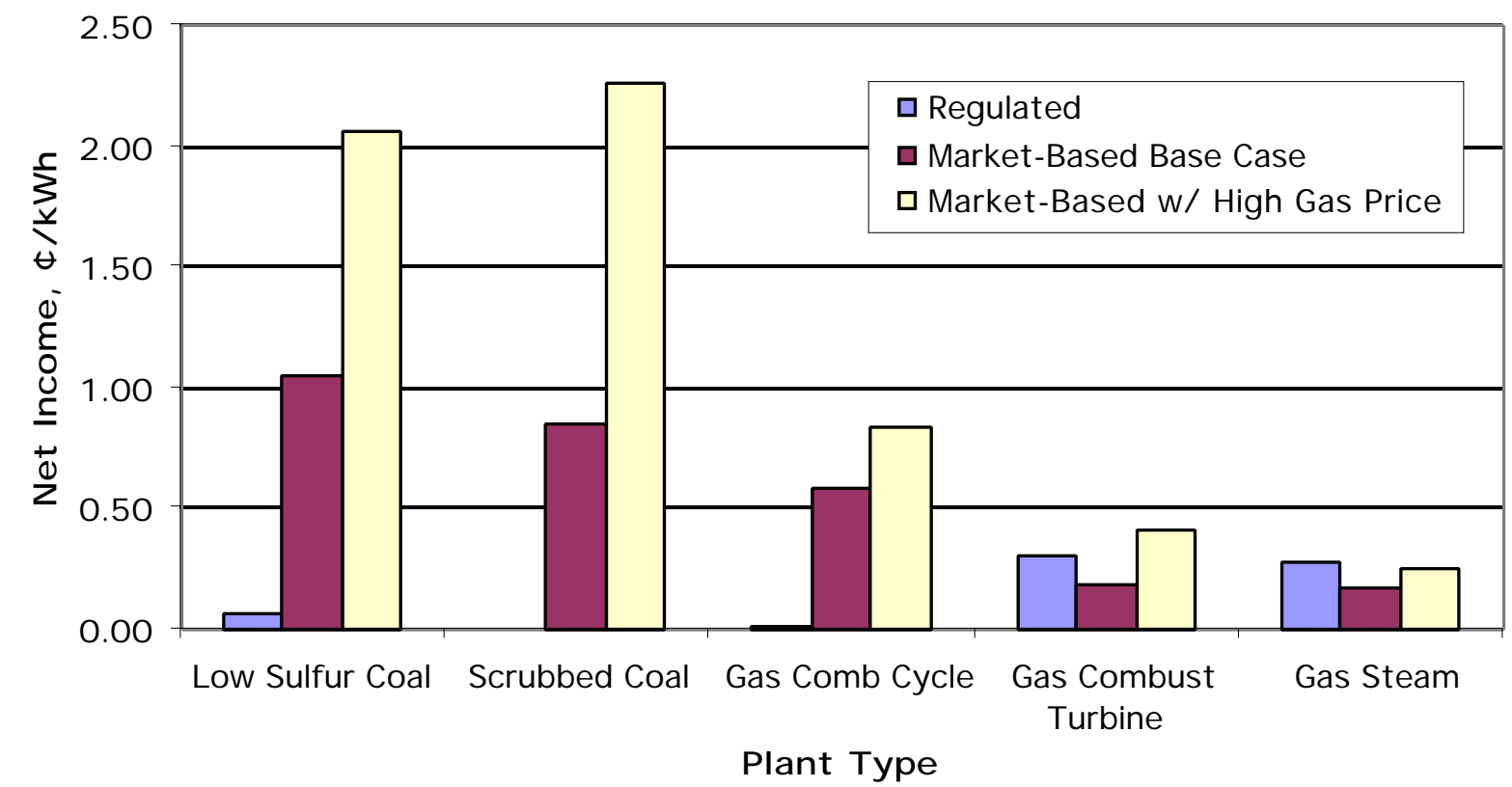

\subsubsection{Higher Coal Plant Availability}

In the base case, we set the coal plants' forced and planned outage rates based on historical data and the assumption that they were always run when available (Table 3). However, their actual outage rates may be higher than calculated, either because of a mistaken assumption or economic factors that caused generation to be lower than the maximum possible. To test this, we set the forced and planned outage rates for coal plants at $6.6 \%$ and $9.7 \%$ respectively, based on EIA estimates for coal technologies (EIA 2000).

With the increase in coal plant availability, generation-related prices drop both for the regulated and market-based scenarios. Regulated prices drop $0.2 \varnothing / \mathrm{kWh}$, while market-based prices drop 0.5 to $0.7 \phi / \mathrm{kWh}$, depending on class. As a consequence, residential rates are only $0.31 \phi / \mathrm{kWh}$ more and industrial $0.71 \phi / \mathrm{kWh}$ more than regulated rates (Table 19 and Figure 17).

Table 19: Increase in market-based prices compared to regulated prices with added availability of coal plants, $c / \mathrm{kWh}$

\begin{tabular}{l|ccc} 
& Base Case & $\begin{array}{c}\text { Added Coal Plant } \\
\text { Availability }\end{array}$ & $\begin{array}{c}\text { Added Coal Availability plus } \\
\text { \$23/kW Capacity Charge }\end{array}$ \\
\hline Residential & 0.80 & 0.31 & 0.96 \\
Commercial & 0.99 & 0.69 & 1.10 \\
Industrial & 0.99 & 0.71 & 1.09 \\
Other & 1.07 & 0.82 & 1.15 \\
Total Coal Plant Net & $346 \mathrm{M} \$$ & $314 \mathrm{M} \$$ & $402 \mathrm{M} \$$ \\
Income, M\$ & & &
\end{tabular}


Figure 17: Customer prices from the base case and with higher coal plant availabilities

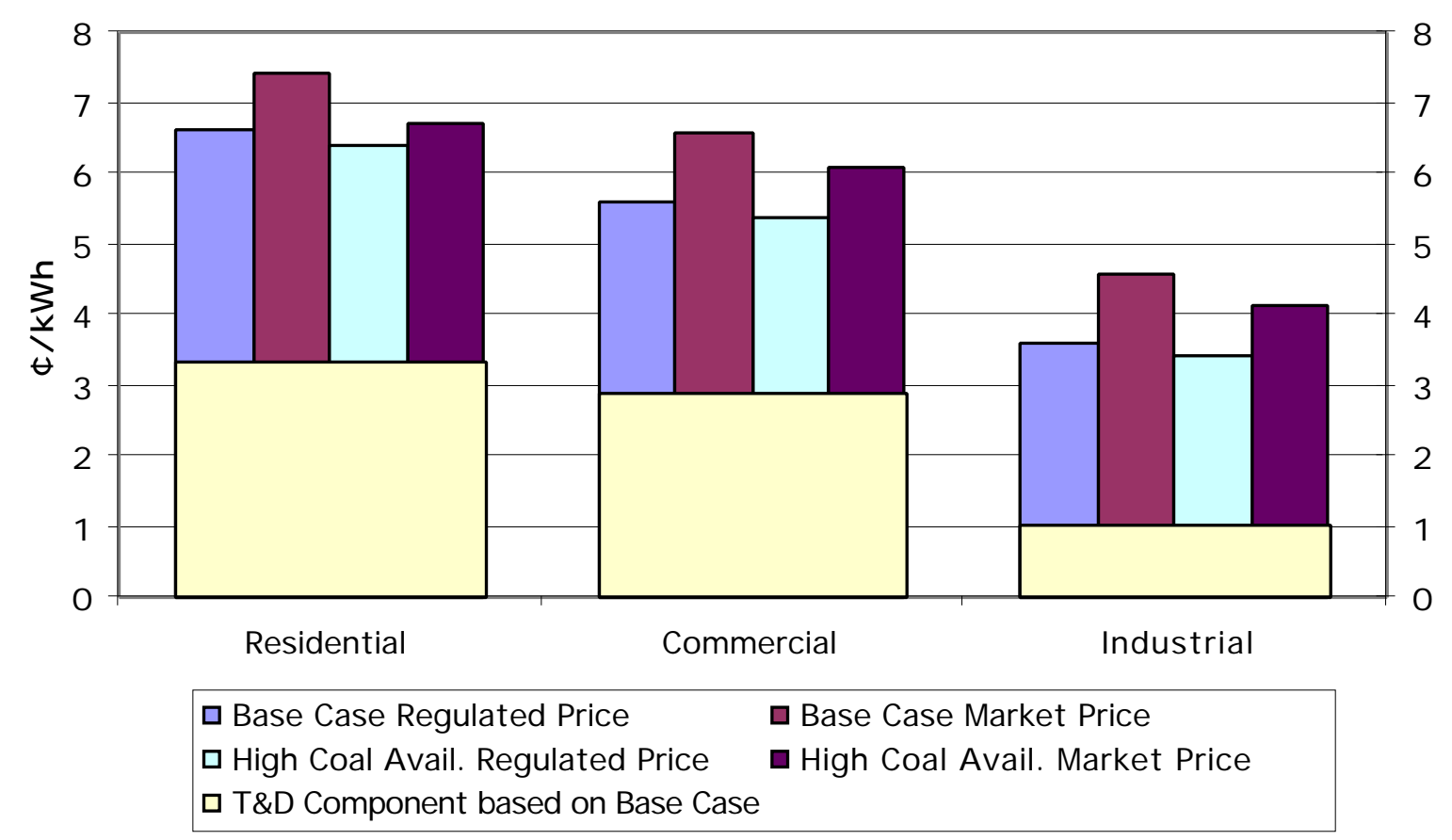

As mentioned in section 4.2, higher availabilities and lowered forced outages can lower the price and duration of the constrained supply period when prices increase due to elasticity. In this sensitivity, the length of time is only $0.2 \%$ of the peak season (versus 1.4\%) and the price averages only $35 \phi / \mathrm{kWh}$ (versus $52 \phi / \mathrm{kWh}$ ).

In addition, higher coal generation means less gas- and oil-fired generation. The combination of lower prices and less generation mean these mid-level and peaking plants lose money. For example, gas steam plants collectively lose $\$ 50$ million (Table 20), when under regulation they would earn \$36 million and in the base case would earn \$22 million. They will need to raise their bid prices above marginal costs in order to recover their fixed costs, not to mention any profits. Alternatively, they may be forced into bankruptcy and have their creditors either write down the assets and keep operating, or (if fixed O\&M costs are not covered) shut down.

Several mechanisms have been explored on recovery of costs to ensure generation adequacy using ORCED (Hirst and Hadley 1999). These include establishment of a separate capacity market to ensure adequate reserves, or increases in energy prices above marginal costs to recover fixed costs and increase profits during times of peak demand and constrained supplies. Both mechanisms have been employed in other states or by bidders in those states' markets, to varying degrees of success. Regardless of the mechanism, the result is higher average prices for power. 
Table 20: Financial results for each plant type with higher coal plant availability, M\$

\begin{tabular}{|c|c|c|c|c|c|c|c|c|c|c|}
\hline \multirow{2}{*}{$\begin{array}{l}\text { Plant } \\
\text { type }\end{array}$} & \multirow{2}{*}{$\begin{array}{l}\text { Capa- } \\
\text { city } \\
\text { MW }\end{array}$} & \multirow{2}{*}{$\begin{array}{l}\text { Output } \\
\text { MWyr }\end{array}$} & \multicolumn{7}{|c|}{ Restructured Market Finances } & \multirow{2}{*}{$\begin{array}{c}\text { Regulated } \\
\text { Net } \\
\text { Income* }\end{array}$} \\
\hline & & & Revenue & $\begin{array}{l}\text { Var.t } \\
\text { Start } \\
\text { Cost }\end{array}$ & $\begin{array}{l}\text { Fixed } \\
\text { O\&M } \\
\text { Cost }\end{array}$ & $\begin{array}{l}\text { Non- } \\
\text { Equity } \\
\text { Capital }\end{array}$ & $\begin{array}{l}\text { Pre-Tax } \\
\text { Income }\end{array}$ & $\begin{array}{c}\text { Income } \\
\text { Taxes }\end{array}$ & $\begin{array}{c}\text { Net } \\
\text { Income }\end{array}$ & \\
\hline Coal_L & 4,348 & 3,635 & 923 & 338 & 48 & 147 & 390 & 122 & 269 & 17 \\
\hline Coal_s & 520 & 435 & 110 & 43 & 6 & 35 & 26 & 0 & 26 & 0 \\
\hline Gas CC & 766 & 420 & 111 & 85 & 7 & 9 & 10 & 1 & 9 & 1 \\
\hline Gas CT & 505 & 49 & 15 & 11 & 2 & 9 & -8 & -2 & -6 & 2 \\
\hline Gas ST & 5,707 & 1,064 & 327 & 271 & 34 & 93 & -72 & -22 & -50 & 36 \\
\hline Hydro & 775 & 304 & 86 & 5 & 12 & 12 & 57 & 0 & 57 & 0 \\
\hline M-Coal & 287 & 260 & 65 & 29 & 4 & 22 & 11 & 0 & 11 & 0 \\
\hline M-Gas & 146 & 129 & 32 & 33 & 1 & 4 & -6 & 0 & -6 & 0 \\
\hline Oil CT & 30 & 0.02 & 0.06 & 0.02 & 0.09 & 0.17 & -0.21 & -0.07 & -0.14 & 0.03 \\
\hline \multirow[t]{2}{*}{ P. Stor } & 260 & 0 & 5 & 4 & 4 & 13 & -15 & 0 & -15 & 0 \\
\hline & 13,344 & 6,294 & 1,676 & 820 & 119 & 343 & 393 & 99 & 294 & 55 \\
\hline
\end{tabular}

${ }^{*}$ Regulated net income for municipal- and cooperative-owned plants is zero since debt-financed.

For example, adding a capacity charge of $\$ 23 / \mathrm{kW}$-year payable to all plants when they are available raises the collective net income for the gas steam plants from $-\$ 50$ million to $\$ 23$ million, about the same as in the base case. (The amount used in this example is just to equalize the net income of the gas steam plants and is not necessarily what would be selected.) The resulting customer price increases in this example are higher than the price increases in the base case, with the extra revenue going to coal plant profits (Table 19 and Figure 18). The actual method and amount that peaking and mid-level units would or could raise prices are dependent on a number of factors such as market design, interconnections with other systems, demand responsiveness, or availability of new capacity.

Figure 18: Net income for plant types under sensitivities with higher coal availability

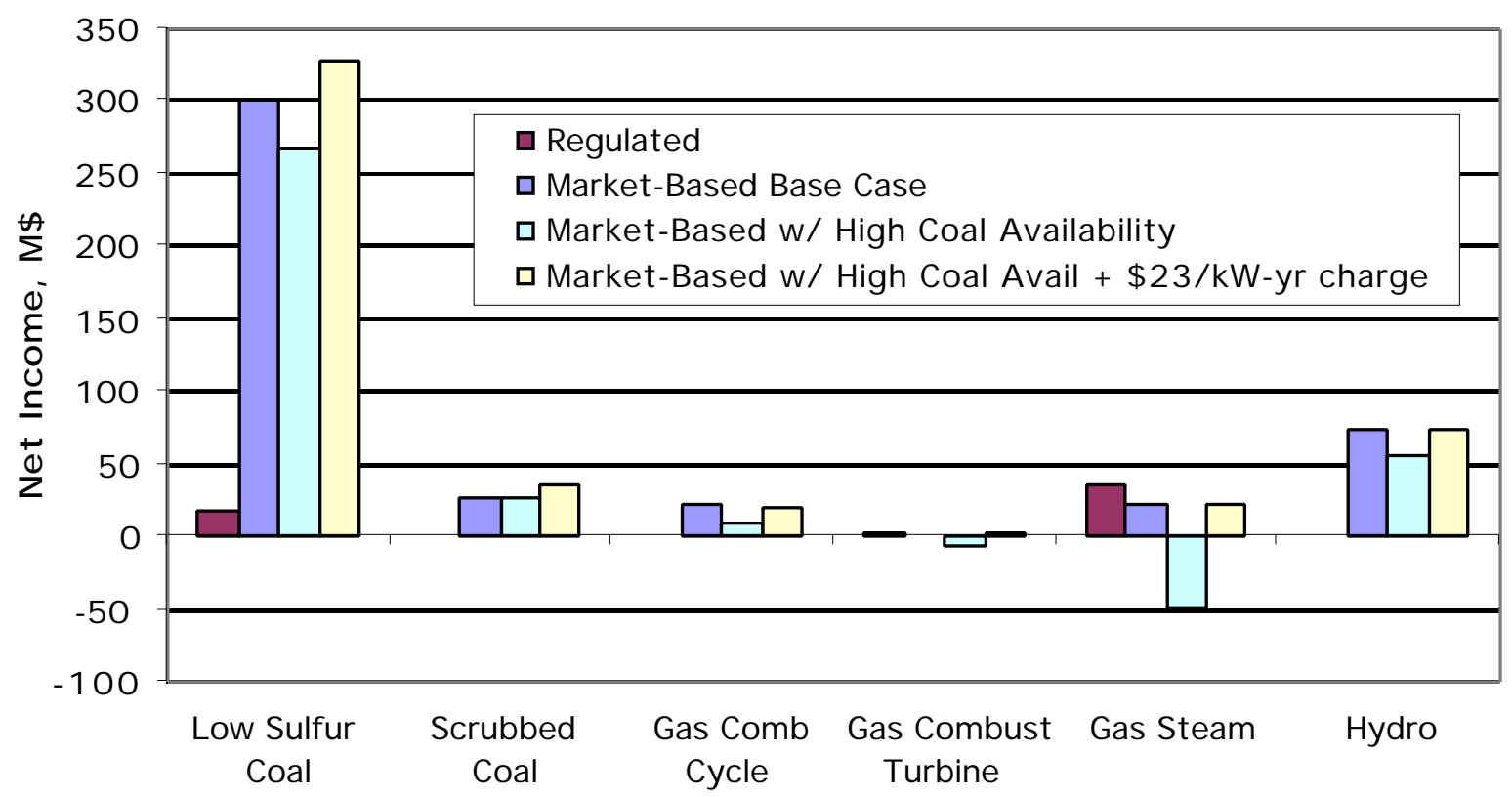





\section{Conclusions}

Overall, Oklahoma is a low-cost power state. However, this statement masks the fact that it is a mixture of low-cost coal-fired plants and mid-cost gas-fired plants. In a regulated market based on average costs, the costs of all production are combined to provide relatively low costs to customers. However, in a restructured market the market-clearing price will largely be defined by the price of the highest marginal cost plant operating at the time. In Oklahoma, this will be gas-fired capacity most of the time. Consequently, prices will rise so these plants will recover their marginal costs. The low-cost coal plants will receive these higher prices as well, resulting in higher profits than under regulated rates.

Another way to look at this is through the idea of "stranded costs". In some areas of the country, utilities had assets that would not be profitable under restructuring, such as high cost nuclear power plants or purchase contracts for power at prices above the market rates. These assets were "stranded" in the sense that they were acquired under a regulatory framework that promised a reasonable rate of return on prudent investments, but they would not receive this return under the new market structure. To compensate, utilities in restructured markets across the country were allowed to recoup the differential in income between the regulated market and the new restructured market. While the utilities held assets that would be unprofitable in the restructured market, they also held assets that would be more profitable; the total amount to be recovered depended on the net profitability of their total assets.

Oklahoma appears to have the opposite problem. If market pricing is based on the marginal costs of plants, then more of its plants will be profitable than unprofitable. It will have "negative stranded costs". It may be necessary that in defining the restructured market, a mechanism will need to be established to compensate ratepayers for these costs, the converse of what has happened in other states.

Several caveats should be placed on this analysis. We defined the electricity market for Oklahoma as a single, largely self-contained market. Aside from capital cost differences between types of ownership (IOU versus municipal), no distinction was made based on the existing ownership. Net asset valuations were made using simplifying assumptions in addition to plantspecific information on investment. More plant-specific capital cost parameters may change the net income received under market-based prices for the different plants and the regulated prices of the system as a whole, although large changes are not expected.

Interactions with neighboring states were modeled solely as an external customer demand based on historical data, and transmission constraints were not explicitly considered. Adding external markets more explicitly would tend to lower the highest prices at peaks because of the greater diversity of supply and demand. However, if external markets have more constrained or higher cost supplies, they may drive market prices higher. The ORCED model does a simplified analysis of dispatching, in that by using a load duration curve rather than hourly time series dispatching factors such as minimum runtimes and ramp rates are lost. We did not explore the possibility of market power, in that suppliers may manipulate supply and prices during times of limited supply. 
Despite the caveats, the results presented appear reasonable based on the assumptions and in accord with economic theory. In Phase II we plan to address some of these concerns, as well as project the market out several years to understand the issues surrounding capacity additions and reliability. We will also do further economic research to understand the broader economic consequences of restructuring on Oklahoma. 


\section{References}

EIA 2000a, National Energy Modeling System: An Overview 2000, DOE/EIA-0581 (2000), U.S. Department of Energy, Washington, DC, March.

http://www.eia.doe.gov/oss/models.html - NEMS

EIA 2000b, Cost and Quality of Fuels for Electric Utility Plants 1999 Tables, DOE/EIA0191(99), U.S. Department of Energy, Washington, DC, June.

http://www.eia.doe.gov/cneaf/electricity/cq/cq sum.html

EIA 2001, Natural Gas Monthly January 2001, DOE/EIA-0130(2001/01), U.S. Department of Energy, Washington, DC, January.

http://www.eia.doe.gov/oil_gas/natural_gas/data_publications/natural_gas_monthly/ngm.html

Hadley, Stanton W. 1996, ORFIN: An Electric Utility Financial and Production Simulator, ORNL/CON-430, Oak Ridge National Laboratory, Oak Ridge, TN, March.

Hadley, S. and E. Hirst 1998, ORCED: A Model to Simulate the Operations and Costs of BulkPower Markets, ORNL/CON-464, Oak Ridge National Laboratory, Oak Ridge, TN, June. http://www.ornl.gov/orced/index.html

Hirst, Eric and Stan Hadley 1999, Maintaining Generation Adequacy in a Restructuring U.S. Electricity Industry, ORNL/CON-472, Oak Ridge National Laboratory, Oak Ridge, TN, October. http://www.ornl.gov/ORNL/BTC/Restructuring/C472.pdf

NERC (North American Electric Reliability Council) 1998, EGADS: Electronic Generating Availability Data System, North American Electric Reliability Council, Princeton, NJ.

http://www.nerc.com/ filez/gar.html

ftp://www.nerc.com/pub/sys/all_updl/gads/gar/gar1998.exe

RDI (Resource Data International) 2001, Powerdat Database, Resource Data International, Boulder, Colo. 



\section{INTERNAL DISTRIBUTION}

1. S. W. Hadley

2. C. R. Hudson

3. D. W. Jones

4. B. J. Kirby

5. J. E. Christian

6. W. G. Craddick

7. T. R. Curlee

8. R. B. Shelton

9. M. A. Brown

10. Central Research Library

11-20. G. T. Scudder

21. Dr. Stephen G. Hildebrand

\section{EXTERNAL DISTRIBUTION}

22. Dr. Lilia A. Abron, President, PEER Consultants, P.C., 1460 Gulf Blvd. Apt. 1103, Clearwater, Florida 33767

23. Dr. Douglas C. Bauer, Executive Director, Commission on Engineering and Technical Systems, National Research Council, Harris 280, 2001 Wisconsin Ave NW, Washington, D.C. 20007

24. Dr. Susan L. Cutter, Professor and Chair, Director, Hazards Research Lab, Department of Geography, University of South Carolina, Columbia, South Carolina 29208

25. Mr. P. Richard Rittelmann, FAIA, Executive Vice President, Burt Hill Kosar Rittelmann Associates, 400 Morgan Center, Butler, Pennsylvania 16001-5977

26. Dr. Susan F. Tierney, The Economic Resource Group, Inc., One Mifflin Place, Cambridge, Massachusetts 02138

27. Dr. C. Michael Walton, Ernest H. Cockrell Centennial Chair In Engineering, Department of Civil Engineering, University of Texas at Austin, Austin, Texas 78712-1076 